\title{
ERS statement on chest imaging in acute respiratory failure
}

\author{
Davide Chiumello ${ }^{1,2}$, Giuseppe Francesco Sferrazza Papa ${ }^{3}$, Antonio Artigas ${ }^{4,5}$, \\ Belaid Bouhemad ${ }^{6}$, Aleksandar Grgic ${ }^{7}$, Leo Heunks ${ }^{8}$, Klaus Markstaller ${ }^{9}$, \\ Giulia M. Pellegrino ${ }^{2,3}$, Lara Pisani ${ }^{10}$, David Rigau ${ }^{11}$, Marcus J. Schultz ${ }^{12}$, \\ Giovanni Sotgiu (13) ${ }^{13}$, Peter Spieth ${ }^{14,15}$, Maurizio Zompatori ${ }^{16}$ and \\ Paolo Navalesi ${ }^{17}$
}

@ERSpublications

A variety of chest imaging techniques are now available for assessing patients with acute respiratory failure. This statement highlights characteristics, clinical indications and limitations of each technique as a guide for patient management. http://bit.ly/2XxYOd7

Cite this article as: Chiumello D, Sferrazza Papa GF, Artigas A, et al. ERS statement on chest imaging in acute respiratory failure. Eur Respir J 2019; 54: 1900435 [https://doi.org/10.1183/13993003.00435-2019].

ABSTRACT Chest imaging in patients with acute respiratory failure plays an important role in diagnosing, monitoring and assessing the underlying disease. The available modalities range from plain chest X-ray to computed tomography, lung ultrasound, electrical impedance tomography and positron emission tomography. Surprisingly, there are presently no clear-cut recommendations for critical care physicians regarding indications for and limitations of these different techniques.

The purpose of the present European Respiratory Society (ERS) statement is to provide physicians with a comprehensive clinical review of chest imaging techniques for the assessment of patients with acute respiratory failure, based on the scientific evidence as identified by systematic searches. For each of these imaging techniques, the panel evaluated the following items: possible indications, technical aspects, qualitative and quantitative analysis of lung morphology and the potential interplay with mechanical ventilation. A systematic search of the literature was performed from inception to September 2018. A first search provided 1833 references. After evaluating the full text and discussion among the committee, 135 references were used to prepare the current statement.

These chest imaging techniques allow a better assessment and understanding of the pathogenesis and pathophysiology of patients with acute respiratory failure, but have different indications and can provide additional information to each other.

This statement was endorsed by the ERS Executive Committee on June 7, 2019.

Received: 01 March 2019 | Accepted after revision: 16 May 2019

This article has supplementary material available from erj.ersjournals.com

Copyright @ERS 2019 


\section{Introduction}

Patients with acute respiratory failure require one or several imaging studies of the chest to diagnose underlying diseases, assess progression and evaluate treatment efficacy. Until a few decades ago, chest imaging of the critically ill consisted solely of chest X-ray (CXR). Additional imaging techniques have become widely available for the critically ill, including chest computed tomography (CT) and, more recently, positron emission tomography (PET) and bedside techniques such as lung ultrasound (LU) and electrical impedance tomography (EIT). Surprisingly, there are presently no clear recommendations for critical care physicians regarding indications for and limitations of these five imaging techniques.

To date, the limited use of chest magnetic resonance imaging (MRI) in pulmonary diseases is due to the physical properties of the pulmonary parenchyma and the long scan time. Although recent technical advances (i.e. parallel imaging, multi-array phase coils and ultra-short echo-time techniques enabling higher image quality and shorter scan time) have provided more detailed information on lung ventilation, inflammation, perfusion and structure, currently MRI is not used in the management of patients with acute respiratory failure. For these reasons, MRI was not included by the current task force.

The purpose of this European Respiratory Society (ERS) statement is to provide physicians with a comprehensive clinical review of chest imaging techniques for the assessment of patients with acute respiratory failure, based on the scientific evidence, as identified by systematic searches. Of the five imaging techniques selected by the Task Force Chairs, three are applicable at the bedside (CXR, LU, EIT) and two (CT and PET) require transfer to the radiological department.

For each of the included imaging techniques, the panel evaluated the following items: indications, technical aspects, qualitative and quantitative analysis of lung morphology and interaction with mechanical ventilation.

\section{Methods}

The ERS Scientific Committee approved the development of a document on imaging techniques in acute respiratory failure by a task force (TF-2016-01) on May 2016 aimed at summarising the relevant literature. The task force was composed of several experts and chaired by D. Chiumello and P. Navalesi. All members disclosed potential conflicts of interest according to ERS policies.

\section{Search}

A systematic search of the literature on the five imaging techniques (CXR, LU, CT, PET and EIT) was performed from inception to September 2018 on Medline/PubMed (National Library of Medicine, USA). The search was limited to articles in English and on humans aged $>18$ years. The keywords included in supplementary tables S1-S4 were used as literature search terms and limited to original studies.

\section{Manuscript preparation}

Task force members were divided into five groups (LP and AA for CXR; DC and GSP for PET; LH, MS, $\mathrm{MZ}$ and KM for CT; GP and BB for LU; PS for EIT). Each group focused on a single technique and its use in a disease entity selected $a$ priori by the Task Force Chairs (pneumonia, chronic obstructive

Affiliations: ${ }^{1}$ SC Anestesia e Rianimazione, Ospedale San Paolo - Polo Universitario, ASST Santi Paolo e Carlo, Milan, Italy. ${ }^{2}$ Dipartimento di Scienze della Salute, Centro Ricerca Coordinata di Insufficienza Respiratoria, Università degli Studi di Milano, Milan, Italy. ${ }^{3}$ Casa di Cura del Policlinico, Dipartimento di Scienze Neuroriabilitative, Milan, Italy. ${ }^{4}$ Corporacion Sanitaria, Universitaria Parc Tauli, CIBER de Enfermedades Respiratorias Autonomous University of Barcelona, Sabadell, Spain. ${ }^{5}$ Intensive Care Dept, University Hospitals Sagrado Corazon - General de Cataluna, Quiron Salud, Barcelona-Sant Cugat del Valles, Spain. 'Service d'Anesthésie - Réanimation, Université Bourgogne - Franche Comtè, Incumr 866L, Dijon, France. ${ }^{7}$ Dept of Nuclear Medicine, Saarland University Medical Center, Homburg, Germany. ${ }^{8}$ Dept of Intensive Care Medicine, Amsterdam UMC, Vrije Universiteit Amsterdam, Amsterdam, The Netherlands. ${ }^{9}$ Dept of Anesthesia, General Intensive Care Medicine and Pain Therapy, Medical University of Vienna, Vienna, Austria. ${ }^{10}$ Respiratory and Critical Care Unit, Alma Mater Studiorum, University of Bologna, Sant'Orsola Malpighi Hospital, Bologna, Italy. ${ }^{11}$ Cochrane Iberoamerica, Barcelona, Spain. ${ }^{12}$ Mahidol-Oxford Tropical Medicine Research Unit, Mahidol University, Bangkok, Thailand. ${ }^{13}$ Clinical Epidemiology and Medical Statistics Unit, Dept of Clinical and Experimental Medicine, University of Sassari, Sassari, Italy. ${ }^{14}$ Dept of Anesthesiology and Critical Care Medicine, University Hospital Carl Gustav Carus, Technische Universität Dresden, Dresden, Germany. ${ }^{15}$ Center for Clinical Research and Management Education, Division of Health Care Sciences, Dresden International University, Dresden, Germany. ${ }^{16}$ Multimedica IRCCS, S. Giuseppe Hospital, Milan, Italy.

${ }^{17}$ Anaesthesia and Intensive Care, Department of Medical and Surgical Sciences, University of Magna Graecia, Catanzaro, Italy.

Correspondence: Davide Chiumello, SC Anestesia e Rianimazione, ASST Santi Paolo e Carlo, Via Di Rudinì, Milan, Italy. E-mail: davide.chiumellodunimi.it 
pulmonary diseases (COPD), acute heart failure, pneumothorax, pleural effusion, acute lung injury and acute respiratory distress syndrome (ARDS)). For each technique, a narrative summary was provided for contextualisation, which summarised certainty of evidence and relevant features. Feedback was provided by electronic communication. This is a statement document, thus no formal assessment of the evidence quality was performed and it does not include recommendations for clinical practice. The final approved version was peer reviewed.

\section{Results of the literature search}

Figure 1 provides an overview of the literature search. The initial search identified 1833 papers. After manual screening of titles and abstracts 1220 papers were excluded and 613 were considered as potentially relevant. After evaluation of the full texts and discussion among the committee, 493 were excluded for the following reasons: 350 were case reports, 61 were reviews, 25 were deemed too small a series (the expert and the methodologist agreed on two cut-offs: 10 subjects for PET and EIT, and 20 for CXR, LUS and CT), 16 were considered to be inappropriate for subject characteristics (e.g. paediatric studies) and 41 references were discarded for other reasons.

An additional search of bibliographies and authors' personal files provided nine papers. Six additional papers were added after updating the search in September 2018. Thus, a total of 135 references were used to prepare the current statement.

\section{Chest X-ray}

The studies on CXR used to prepare this statement are listed in table 1. Bedside CXR remains one of the most frequently prescribed imaging techniques, providing helpful information for the monitoring of critically ill patients. Although lots of effort has been made to improve technical aspects, numerous limitations of bedside CXR persist, including bedside attenuation factor, X-ray intensity and distance to the thorax, and synchronisation to mechanical ventilation. In addition, patients are often uncooperative and difficult to position, thus increasing procedure time and cost. All these factors may hinder the correct interpretation of CXR.

\section{ARDS}

ARDS is defined by the acute onset of bilateral opacities on chest radiography not fully explained by effusions, lobar/lung collapse, nodules or oedema [1].

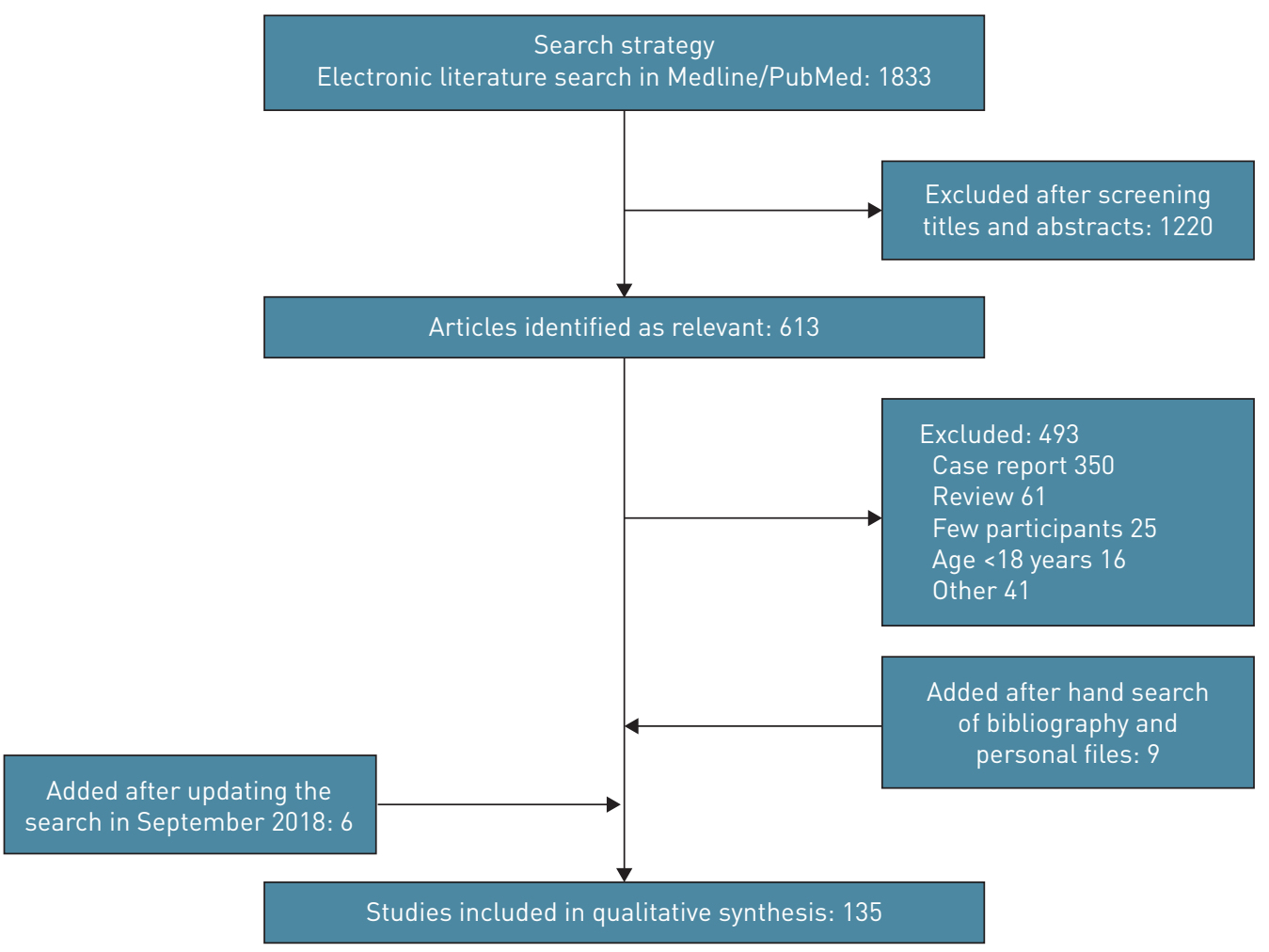

FIGURE 1 Flow chart of the study protocol process. 


\begin{tabular}{|c|c|c|c|c|c|c|}
\hline Disease & Reference & First author & Aim & Subjects & Study design & Main results \\
\hline ARDS & [2] & Rubenfeld GD & $\begin{array}{l}\text { To study the inter-observer variability in applying } \\
\text { the American European radiographic criteria for } \\
\text { ARDS }\end{array}$ & 28 & Prospective & $\begin{array}{l}\text { The radiographic criteria showed high } \\
\text { inter-observer variability }\end{array}$ \\
\hline ARDS & [3] & Figueroa-Casas JB & $\begin{array}{l}\text { To evaluate the diagnostic accuracy of CXRs to } \\
\text { detect pulmonary abnormalities in ARDS }\end{array}$ & 90 & Retrospective & $\begin{array}{l}\text { Accuracy of CXRs to detect pulmonary } \\
\text { abnormalities was limited }\end{array}$ \\
\hline ARDS & [4] & Frolich S & To evaluate accuracy of clinical diagnoses of ARDS & 51 & Retrospective & $\begin{array}{l}\text { Only one-third of ARDS was recognised on } \\
\text { clinical records }\end{array}$ \\
\hline ARDS & [5] & Peng J-M & $\begin{array}{l}\text { To examine the effect of training material on the } \\
\text { accuracy of CXR interpretations for ARDS } \\
\text { diagnosis }\end{array}$ & $\begin{array}{l}286 \\
\text { intensivists }\end{array}$ & Prospective & $\begin{array}{l}\text { The radiographic diagnostic accuracy and } \\
\text { inter-rater agreement were poor and not } \\
\text { improved by training }\end{array}$ \\
\hline ARDS & [6] & Goddard SL & $\begin{array}{l}\text { To test an educational intervention to improve the } \\
\text { radiographic identification of ARDS }\end{array}$ & $\begin{array}{c}464 \\
\text { intensivists }\end{array}$ & Prospective & $\begin{array}{l}\text { Recognition of radiographic criteria for ARDS } \\
\text { was low, with poor agreement }\end{array}$ \\
\hline AHF & [7] & Halperin BD & To identify presence of excess lung water & 12 & Prospective & $\begin{array}{l}\text { CXRs were not accurate in monitoring modest } \\
\text { changes in lung water in critically ill patients }\end{array}$ \\
\hline AHF & [8] & Martin GS & To identify temporal changes in fluid balance & 37 & Prospective & $\begin{array}{l}\text { Objective radiographic measures of intravascular } \\
\text { volume were more accurate than subjective } \\
\text { measures }\end{array}$ \\
\hline AHF & [9] & Thomason JW & $\begin{array}{l}\text { To identify hydrostatic and permeability pulmonary } \\
\text { oedema }\end{array}$ & 33 & Prospective & $\begin{array}{l}\text { Objective measurements of CT ratio and VPW } \\
\text { correlated with pulmonary artery occlusion } \\
\text { pressure }\end{array}$ \\
\hline AHF & [10] & Farshidpanah S & $\begin{array}{l}\text { To identify hydrostatic and permeability pulmonary } \\
\text { oedema }\end{array}$ & 80 & Retrospective & $\begin{array}{l}\text { Objective measurements of CT ratio and VPW } \\
\text { correlated with cardiogenic pulmonary } \\
\text { oedema }\end{array}$ \\
\hline Pneumonia & [11] & Lefcoe MS & $\begin{array}{l}\text { To examine diagnostic accuracy of CXRs for } \\
\text { pneumonia }\end{array}$ & 62 & Prospective & $\begin{array}{l}\text { CXRs were not accurate in predicting the } \\
\text { presence of pneumonia }\end{array}$ \\
\hline Pneumonia & [12] & Butler KL & $\begin{array}{l}\text { To examine diagnostic accuracy of CXRs for } \\
\text { pneumonia }\end{array}$ & 20 & Prospective & $\begin{array}{l}\text { CXRs did not improve the clinician's ability to } \\
\text { diagnose pneumonia }\end{array}$ \\
\hline Pneumonia & [13] & Moine $\mathrm{P}$ & $\begin{array}{l}\text { To describe radiological features of severe } \\
\text { community-acquired pneumococcal pneumonia }\end{array}$ & 132 & Prospective & $\begin{array}{l}\text { CXRs were not accurate in detecting pneumonia } \\
\text { aetiology }\end{array}$ \\
\hline Pneumothorax & [14] & Schulman $\mathrm{Cl}$ & $\begin{array}{l}\text { To determine optimal time for CXRs after chest } \\
\text { tube positioning }\end{array}$ & 75 & Prospective & $\begin{array}{l}\text { Early CXRs excluded the development of a } \\
\text { clinically significant pneumothorax }\end{array}$ \\
\hline Pneumothorax & [15] & Pizano LR & $\begin{array}{l}\text { To determine optimal time for CXRs after chest } \\
\text { tube removal }\end{array}$ & 75 & Prospective & $\begin{array}{l}\text { After } 1 \mathrm{~h} \text { from tube removal the CXRs identified } \\
\text { all the pneumothoraces }\end{array}$ \\
\hline $\begin{array}{l}\text { Pleural } \\
\text { effusion }\end{array}$ & [16] & Emamian SA & $\begin{array}{l}\text { To determine the diagnostic accuracy of pleural } \\
\text { effusion by CXR }\end{array}$ & $\begin{array}{c}24 \\
\text { measures }\end{array}$ & Prospective & $\begin{array}{l}\text { Diagnostic accuracy of pleural effusion on supine } \\
\text { CXRs was acceptable }\end{array}$ \\
\hline $\begin{array}{l}\text { Pleural } \\
\text { effusion }\end{array}$ & [17] & Brixey AG & $\begin{array}{l}\text { To determine the diagnostic accuracy of pleural } \\
\text { effusion by CXR }\end{array}$ & 61 & Retrospective & $\begin{array}{l}\text { Diagnostic accuracy of pleural effusion was the } \\
\text { same between lateral and anterior-posterior } \\
\text { CXRs }\end{array}$ \\
\hline
\end{tabular}


Although the radiographic criterion of "bilateral pulmonary infiltrates or opacities" on CXR is essential for the diagnosis of ARDS, significant inter-observer variability is reported [2]. Compared to chest CT, the accuracy of CXR in identifying pulmonary abnormalities in patients meeting criteria for ARDS is limited and unrelated to disease severity, as defined by the extent of oxygenation derangement [3]. A retrospective single-centre study showed that only $31 \%$ of patients with ARDS according to the current definition presented with histopathological signs of diffuse alveolar damage (a finding pathognomonic for ARDS) [4]. A recent study evaluated whether diagnostic accuracy could be improved by an educational intervention based on a set of chest radiographs. Though some improvement in diagnostic accuracy after the educational intervention was observed, the overall accuracy remained poor [5]. A multicentre randomised trial using an online educational module of the Berlin definition on ARDS failed to demonstrate any improvement in the accuracy or in the identification of ARDS patients among critical care clinicians and research staff [6].

\section{Acute heart failure}

CXRs performed at the bedside with portable equipment are often used to identify and quantify the presence of pulmonary oedema in the intensive care unit (ICU). However, a supine position and the potential presence of other multiple radiographic abnormalities often hinder CXR interpretation. In addition, the distinction between hydrostatic and permeability pulmonary oedema, as well as quantitating the amount of lung water, is extremely problematic [7]. Although a relationship has been found between a score based on CXR findings and the amount of extravascular lung water, the evolution of extravascular lung water was not associated with score changes [7]. To improve diagnostic accuracy in patients with acute heart failure, some radiological signs, such as the cardiothoracic ratio, vascular pedicle width and dimensions of the mediastinal silhouette of the great vessels, have been proposed $[8,9]$. A vascular pedicle width exceeding $70 \mathrm{~mm}$ has acceptable sensitivity and specificity in discriminating cardiogenic from non-cardiogenic pulmonary oedema [10].

\section{COPD}

Although CXR is usually performed in patients with COPD exacerbation, it has low sensitivity for the detection of airflow obstruction. During acute exacerbation the predominant pathological changes are found within the airways, with abnormal images only in very few cases. In this setting, CXR is useful to rule out pneumonia or to exclude alternative diagnoses and complications such as decompensated heart failure, massive pleural effusion, atelectasis or pneumothorax.

\section{Pneumonia}

Conventional CXR is the preferred imaging modality in critical care settings for both the detection of new infiltrates and for monitoring response to therapy, with the possibility of detecting early complications including cavitations, abscesses, pneumothoraces and pleural effusions. However, owing to the well-known difficulties involved in radiographic interpretation of portable CXR in critical care, a diagnosis of pneumonia may be difficult. Using protected brush catheter specimens as the gold standard for the diagnosis of nosocomial pneumonia, LEFCOE et al. [11] demonstrated a CXR sensitivity in detecting pneumonia associated with positive cultures of 0.60 and 0.64 , as interpreted by two radiologists, with low reproducibility between the two examiners. In a small group of patients with clinical suspicion of ventilator-associated pneumonia, the sensitivity of CXR in determining the presence of ventilator-associated pneumonia was $25 \%$, with a specificity of $75 \%$ and an accuracy of 0.45 using protected brush catheter and microbiology as reference [12]. A multicentre French study found that the occurrence of alveolar consolidations with lobar distribution was more frequently associated with severe pneumococcal pneumonia, although the value of this prediction was rather limited [13].

\section{Pneumothorax}

Controversy exists regarding the optimal time interval to identify a pneumothorax on CXR after both chest tube positioning and removal. SCHULMAN et al. [14] evaluated both an immediate and a delayed approach (following morning) with CXR after chest tube positioning. Of the 31 patients with a pneumothorax on follow-up, 22 were "early" and nine "late", but none of the patients in the late group presented with a clinically significant pneumothorax. Concerning the timing of CXRs after tube removal, PIZANo et al. [15] found that serial CXRs performed at approximately 1,10 and $36 \mathrm{~h}$ did not identify different rates of pneumothoraces in mechanically ventilated patients.

\section{Pleural effusion}

Owing to technical limitations, pleural effusions, particularly when small, can be difficult to diagnose on CXR performed in a supine position. A previous report on the detection of pleural effusions on supine 
CXR showed an overall accuracy of $82 \%$, with better results for larger pleural effusions (>300 mL) [16]. The accuracy for parapneumonic effusions is similar for anteroposterior and lateral CXR [17].

\section{Ultrasound}

The studies on LU used to prepare this statement are listed in table 2. Because the ultrasound beam does not penetrate the lung, LU is able to explore only the pleural line and the related artefacts that are generated at the pleural line. The pleural line appears as a hyperechoic sliding line, moving forwards and backwards in the course of inspiration and expiration. The key artefacts are A- and B-lines. B-lines correspond to various degrees of lung aeration and the quantity is related to the amount of extravascular lung water. Multiple and well-separated vertical B-lines correspond to a moderate decrease in lung aeration resulting from interstitial syndrome. Coalescent B-lines correspond to a more severe decrease in lung aeration resulting from partial filling of alveolar spaces by pulmonary oedema or confluent bronchopneumonia. Lung consolidation is a tissue-like echotexture pattern due to a loss of aeration of lung parenchyma [18].

\section{ARDS}

Lung infiltrates of the pulmonary alveolar interstitial space caused by ARDS may show consolidations and B-line patterns. However, these findings are nonspecific of ARDS because the syndrome encompasses consolidated regions, ground glass areas and normally aerated regions. As a consequence, LU patterns of ARDS may encompass B-lines, pleural line abnormalities (absent or reduced lung sliding, thickening or irregularities), consolidations and spared areas [19,20]. These LU findings, together with impaired oxygenation, are simple tools to diagnose ARDS [21,21], especially when combined with echocardiography [22]. LU has helped assess the incidence and outcomes of patients with ARDS in settings with limited resources [23].

The increase of lung water in ARDS can be detected by LU, and the LU score of B-lines is closely related to several prognostic indices [24].

Given that LU patterns are determined by the level of aeration, lung re-aeration can be assessed by tracking LU changes. This was first demonstrated by trans-oesophageal echography [25-27]. It has been proven that during positive end-expiratory pressure (PEEP) recruitment manoeuvres, the gas increase can be monitored by measuring the area of consolidated, dependent right lower lobes [28]. However, it may be more accurate to use scores based on a whole lung examination protocol [29]. Despite the fact that LU scores have proven to be a valid tool for assessing regional and global lung aeration, global LU score variations should not be used for bedside assessment of PEEP-induced recruitment. In addition, LU cannot be used to estimate lung hyperinflation [30].

\section{Acute heart failure}

Although nonspecific, B-lines can detect extravascular lung water. Simple scores based on numbers of B-lines correlate with surrogate markers of pulmonary oedema [31-33] because B-lines decrease during haemodialysis $[34,35]$. B-lines could also be correlated with pulmonary wedge pressure $[24,36]$.

Cardiogenic pulmonary oedema results from increased intravascular hydrostatic pressure. As a consequence, the distribution of alveolar flooding is homogeneous. The LU pattern of cardiogenic pulmonary oedema is characterised by the presence of multiple B-lines in all thoracic regions [19]. Pleural effusion, moderately or severely decreased left ventricular function, and a small inferior vena cava diameter point towards cardiogenic pulmonary oedema instead of ARDS in acutely hypoxaemic patients [20]. LU has been used in the pre-hospital setting [37] and in the emergency department to manage patients with cardiogenic pulmonary oedema, thus proving to be a reliable bedside tool to guide therapy $[38,39]$.

\section{COPD}

In COPD patients, acute exacerbation usually shows a normal LU pattern despite the presence of acute respiratory failure. On the contrary, the presence of B-lines suggests the presence of an associated alveolar interstitial syndrome with an acceptable accuracy [40]. Chest ultrasonography (heart and lung) in patients admitted with acute respiratory failure allows a more accurate diagnosis of decompensated COPD compared to a standard diagnostic approach, based on physical examination, CXR and biological data [41].

\section{Pneumonia}

$\mathrm{LU}$ is a valid alternative for bedside diagnosis of lung consolidations in community-acquired pneumonia in adults [42], and can provide early detection of interstitial lung involvement in viral pneumonia [43]. In addition, LU can also provide guidance for transthoracic needle aspiration for aetiological diagnosis of patients with complicated pneumonia. This has been confirmed in the ICU and the emergency department [44-52]. 


\begin{tabular}{|c|c|c|c|c|c|c|}
\hline Disease & Reference & First author & Aim & Subjects & $\begin{array}{l}\text { Study } \\
\text { design }\end{array}$ & Main results \\
\hline ARDS & [19] & Copetti R & $\begin{array}{l}\text { To assess the ability of LU to identify ARDS compared } \\
\text { to cardiogenic pulmonary oedema }\end{array}$ & 58 & Prospective & $\begin{array}{l}\text { LU was able to discriminate between ARDS and cardiogenic } \\
\text { pulmonary oedema }\end{array}$ \\
\hline ARDS & {$[20]$} & Sekiguchi H & $\begin{array}{l}\text { To assess the ability of LU to identify ARDS compared } \\
\text { to cardiogenic pulmonary oedema }\end{array}$ & 134 & Prospective & $\begin{array}{l}\text { LU was able to discriminate between ARDS and cardiogenic } \\
\text { pulmonary oedema }\end{array}$ \\
\hline ARDS & {$[21]$} & Bass CM & $\begin{array}{l}\text { To assess the ability of } L U \text { and arterial saturation to } \\
\text { identify ARDS }\end{array}$ & 123 & Prospective & $\begin{array}{l}\text { LU was a useful tool to screen oxygenation impairment } \\
\text { consistent with ARDS }\end{array}$ \\
\hline ARDS & {$[22]$} & Huang D & $\begin{array}{l}\text { To assess the ability of LU to identify ARDS in elderly } \\
\text { patients }\end{array}$ & 51 & Prospective & LU presented similar accuracy compared to chest CT \\
\hline ARDS & [23] & Riviello ED & $\begin{array}{l}\text { To estimate incidence of ARDS according to the Berlin } \\
\text { definition and LU }\end{array}$ & 42 & Prospective & $\begin{array}{l}\text { Using these criteria the incidence of ARDS was significantly } \\
\text { improved }\end{array}$ \\
\hline ARDS & [24] & Zhao Z & To assess prognostic values of LU in ARDS & 21 & Prospective & $\begin{array}{l}\text { Early use of LU was a useful prognostic indicator in ARDS } \\
\text { patients }\end{array}$ \\
\hline ARDS & {$[25]$} & Tsubo T & To evaluate daily lung density changes in ARDS & 15 & Prospective & $\begin{array}{l}\text { LU was able to detect density changes in independent lung } \\
\text { regions in ARDS }\end{array}$ \\
\hline ARDS & [26] & Tsubo T & To evaluate lung density in ARDS & 40 & Prospective & $\begin{array}{l}\text { LU was able to detect density changes in independent lung } \\
\text { regions in ARDS }\end{array}$ \\
\hline ARDS & [27] & Tsubo T & $\begin{array}{l}\text { To evaluate lung density in ARDS during prone } \\
\text { positioning }\end{array}$ & 10 & Prospective & $\begin{array}{l}\text { LU was able to detect changes in density during prone } \\
\text { positioning }\end{array}$ \\
\hline ARDS & [28] & Stefanidis $\mathrm{K}$ & $\begin{array}{l}\text { To evaluate LU in the measurement of pulmonary } \\
\text { recruitment }\end{array}$ & 10 & Prospective & LU could detect non-aerated lung areas during PEEP trials \\
\hline ARDS & [29] & Bouhemad B & $\begin{array}{l}\text { To evaluate LU in the measurement of pulmonary } \\
\text { recruitment }\end{array}$ & 30 & Prospective & LU could detect lung recruitment during PEEP changes \\
\hline ARDS & [30] & Chiumello D & $\begin{array}{l}\text { To assess LU score in the measurement of pulmonary } \\
\text { recruitment }\end{array}$ & 20 & Prospective & $\begin{array}{l}\text { LU score should not be used to assess pulmonary } \\
\text { recruitment }\end{array}$ \\
\hline AHF & [31] & Enghard $\mathrm{P}$ & To evaluate LU in predicting extravascular lung water & 50 & Prospective & LU correlated with extravascular lung water \\
\hline AHF & [32] & Jambrick Z & To evaluate LU in predicting extravascular lung water & 121 & Prospective & LU correlated with extravascular lung water \\
\hline AHF & [33] & Volpicelli G & To evaluate LU in predicting extravascular lung water & 73 & Prospective & LU correlated with extravascular lung water \\
\hline AHF & [34] & Mallamaci F & To evaluate LU in predicting extravascular lung water & 47 & Prospective & $\begin{array}{l}\text { LU correlated with extravascular lung water in } \\
\text { haemodialysis patients }\end{array}$ \\
\hline $\mathrm{AHF}$ & [35] & Noble VE & To evaluate LU in predicting extravascular lung water & 45 & Prospective & $\begin{array}{l}\text { LU score changes correlated with real time extravascular } \\
\text { lung water changes during haemodialysis }\end{array}$ \\
\hline $\mathrm{AHF}$ & [36] & Lichtenstein DA & $\begin{array}{l}\text { To evaluate LU in predicting pulmonary arterial } \\
\text { occlusion pressure }\end{array}$ & 102 & Prospective & $\begin{array}{l}\text { LU score could predict a low pulmonary arterial occlusion } \\
\text { pressure }\end{array}$ \\
\hline AHF & [37] & Laursen $\mathrm{CB}$ & $\begin{array}{l}\text { To evaluate LU in predicting the diagnosis of } \\
\text { cardiogenic pulmonary oedema }\end{array}$ & 40 & Prospective & LU was able to rule out cardiogenic pulmonary oedema \\
\hline $\mathrm{AHF}$ & [38] & Cortellaro F & $\begin{array}{l}\text { To evaluate LU in monitoring the response to therapy } \\
\text { in cardiogenic pulmonary oedema }\end{array}$ & 41 & Prospective & $\begin{array}{l}\text { LU allowed to guide therapy titration in cardiogenic } \\
\text { pulmonary oedema }\end{array}$ \\
\hline AHF & [39] & Martindale JL & $\begin{array}{l}\text { To evaluate LU in monitoring changes in pulmonary } \\
\text { oedema }\end{array}$ & 20 & Prospective & LU improved the clinical management \\
\hline COPD & [40] & Lichtenstein DA & $\begin{array}{l}\text { To assess the relationship between comet tail } \\
\text { artefacts and alveolar interstitial syndrome }\end{array}$ & 121 & Prospective & $\begin{array}{l}\text { Good correlation between the ground glass and comet tail } \\
\text { artefacts }\end{array}$ \\
\hline COPD & [41] & Silva S & $\begin{array}{l}\text { To compare LU with clinical, radiological and } \\
\text { biological data }\end{array}$ & 78 & Prospective & Cardiothoracic ultrasound was a useful diagnostic approach \\
\hline Pneumonia & [42] & Yang PC & To identify LU features associated with pneumonia & 161 & Prospective & $\begin{array}{l}\text { LU was a useful tool in the evaluation of pulmonary } \\
\text { consolidation }\end{array}$ \\
\hline
\end{tabular}




\begin{tabular}{|c|c|c|c|c|c|c|}
\hline Disease & Reference & First author & Aim & Subjects & $\begin{array}{l}\text { Study } \\
\text { design }\end{array}$ & Main results \\
\hline Pneumonia & [43] & Testa A & To evaluate LU features in interstitial pneumonia & 98 & Prospective & LU could provide early detection of interstitial pneumonia \\
\hline Pneumonia & [44] & Reissig A & To identify LU features associated with pneumonia & 30 & Prospective & $\begin{array}{l}\text { LU was a useful tool in the evaluation and follow-up of } \\
\text { patients with pneumonia }\end{array}$ \\
\hline Pneumonia & [45] & Parlamento S & $\begin{array}{l}\text { To evaluate LU in confirming the clinical suspicion of } \\
\text { pneumonia }\end{array}$ & 49 & Prospective & $\begin{array}{l}\text { LU should be considered in the diagnostic workup of } \\
\text { pneumonia }\end{array}$ \\
\hline Pneumonia & [46] & Sperandeo M & $\begin{array}{l}\text { To evaluate LU in confirming the clinical suspicion of } \\
\text { pneumonia }\end{array}$ & 15 & Prospective & $\begin{array}{l}\text { LU was a useful tool in the evaluation and follow-up of } \\
\text { patients with pneumonia }\end{array}$ \\
\hline Pneumonia & [47] & Cortellaro F & $\begin{array}{l}\text { To evaluate LU to confirm the clinical suspicion of } \\
\text { pneumonia }\end{array}$ & 120 & Prospective & $\begin{array}{l}\text { LU should be considered in the diagnostic workup of } \\
\text { pneumonia }\end{array}$ \\
\hline Pneumonia & [48] & Reissig A & $\begin{array}{l}\text { To evaluate LU in the diagnosis of community-acquired } \\
\text { pneumonia }\end{array}$ & 30 & Prospective & $\begin{array}{l}\text { LU had a high accuracy in diagnosing community-acquirec } \\
\text { pneumonia }\end{array}$ \\
\hline Pneumonia & [49] & Bourcier J-E & $\begin{array}{l}\text { To evaluate LU in confirming the clinical suspicion of } \\
\text { pneumonia }\end{array}$ & 144 & Prospective & $\begin{array}{l}\text { LU should be considered as a first-line diagnostic tool for } \\
\text { pneumonia }\end{array}$ \\
\hline Pneumonia & [50] & Corradi F & $\begin{array}{l}\text { To compare LU with CXR in suspected } \\
\text { community-acquired pneumonia }\end{array}$ & 32 & Prospective & $\begin{array}{l}\text { LU should be considered in the first-line diagnosis of } \\
\text { pneumonia }\end{array}$ \\
\hline Pneumonia & [51] & Liu $X$ & $\begin{array}{l}\text { To compare LU with CXR in suspected } \\
\text { community-acquired pneumonia }\end{array}$ & 179 & Prospective & $\begin{array}{l}\text { LU had better diagnostic sensitivity and accuracy for } \\
\text { diagnosing community-acquired pneumonia }\end{array}$ \\
\hline Pneumonia & [52] & Pagano A & $\begin{array}{l}\text { To compare LU with CXR in suspected } \\
\text { community-acquired pneumonia }\end{array}$ & 107 & Prospective & $\begin{array}{l}\text { LU should be considered in the first-line diagnosis of } \\
\text { pneumonia }\end{array}$ \\
\hline Pneumonia & [53] & Lichtenstein DA & To evaluate LU features and diagnosis of pneumonia & 66 & Prospective & $\begin{array}{l}\text { LU could distinguish pneumonia from reabsorption } \\
\text { atelectasis }\end{array}$ \\
\hline Pneumonia & [54] & Bouhemad B & $\begin{array}{l}\text { To evaluate LU for lung re-aeration in } \\
\text { ventilator-associated pneumonia }\end{array}$ & 30 & Prospective & LU accurately estimated lung re-aeration \\
\hline Pneumonia & [55] & Mongodi S & $\begin{array}{l}\text { To evaluate LU for early diagnosis of } \\
\text { ventilator-associated pneumonia }\end{array}$ & 99 & Prospective & $\begin{array}{l}\text { LU was a reliable tool for early ventilator-associated } \\
\text { pneumonia diagnosis }\end{array}$ \\
\hline Pneumothorax & [56] & Lichtenstein DA & $\begin{array}{l}\text { To evaluate the presence of lung point as specific sign } \\
\text { of pneumothorax }\end{array}$ & 66 & Prospective & The lung point allowed the diagnosis of pneumothorax \\
\hline Pneumothorax & [57] & Volpicelli G & $\begin{array}{l}\text { To compare the pneumothorax volume between LU } \\
\text { and chest CT }\end{array}$ & 124 & Prospective & Good correlation between LU and chest CT \\
\hline Pneumothorax & [58] & Dulchavsky SA & To evaluate LU for diagnosis of pneumothorax & 382 & Prospective & LU was a reliable tool for diagnosis of pneumothorax \\
\hline Pneumothorax & [59] & Kirkpatrick AW & To evaluate LU for diagnosis of pneumothorax & 225 & Prospective & LU was a reliable tool for diagnosis of pneumothorax \\
\hline Pneumothorax & [60] & Weekes AJ & $\begin{array}{l}\text { To compare LU with CXR for confirmation of central } \\
\text { venous catheter placement }\end{array}$ & 151 & Prospective & No difference between LU and CXR \\
\hline Pneumothorax & [61] & Vezzani A & $\begin{array}{l}\text { To compare LU with CXR for confirmation of central } \\
\text { venous catheter placement }\end{array}$ & 111 & Prospective & No difference between LU and CXR \\
\hline Pneumothorax & [62] & Maury E & $\begin{array}{l}\text { To compare LU with CXR for confirmation of central } \\
\text { venous catheter placement }\end{array}$ & 58 & Prospective & LU was a more rapid method compared to CXR \\
\hline Pneumothorax & [63] & Saucier S & $\begin{array}{l}\text { To evaluate LU for the detection of pneumothorax after } \\
\text { chest tube removal }\end{array}$ & 50 & Prospective & LU was accurate to detect pneumothorax \\
\hline $\begin{array}{l}\text { Pleural } \\
\text { effusion }\end{array}$ & [64] & Lichtenstein DA & To evaluate the safety of thoracentesis guided by LU & 40 & Prospective & LU guaranteed safety during thoracentesis \\
\hline $\begin{array}{l}\text { Pleural } \\
\text { effusion }\end{array}$ & [65] & Vignon $\mathrm{P}$ & $\begin{array}{l}\text { To assess the ability of LU to predict the amount of } \\
\text { pleural effusion }\end{array}$ & 97 & Prospective & $\begin{array}{l}\text { Expiratory interpleural distance was related to the amount } \\
\text { of pleural effusion }\end{array}$ \\
\hline $\begin{array}{l}\text { Pleural } \\
\text { effusion }\end{array}$ & [66] & Rozycki GS & To evaluate LU for diagnosis of pleural effusion & 47 & Prospective & $\begin{array}{l}\text { LU was a reliable tool for the diagnosis of pleural effusion } \\
\text { in surgically ill patients }\end{array}$ \\
\hline
\end{tabular}




\section{TABLE 2 Continued}

$\begin{array}{ccccccc}\text { Disease } & \text { Reference } & \text { First author } & \text { Aim } & \text { Subjects } & \text { Study } & \text { Main results } \\ \text { design }\end{array}$

LU: lung ultrasound; ARDS: acute respiratory distress syndrome; CT: computed tomography; PEEP: positive end-expiratory pressure; AHF: acute heart failure; COPD: chronic obstructive pulmonary disease; CXR: chest X-ray. 
Performing an accurate diagnosis of ventilator-associated pneumonia in mechanically ventilated patients frequently represents a challenge. By identifying ventilator-associated pneumonia-specific signs (focal areas of interstitial syndrome, small subpleural consolidations, large consolidations and fluid bronchogram), LU can discriminate pneumonia from resorptive atelectasis [53]. Furthermore, LU can accurately estimate the changes in lung aeration in patients with ventilator-associated pneumonia treated with antibiotics [54].

In a multicentre study, the diagnostic performance of a score based on the presence of subpleural consolidations, lobar consolidations and dynamic arborescent/linear air bronchograms was investigated in patients with suspected ventilator-associated pneumonia [55]. The LU-based score had a higher sensitivity and specificity in predicting ventilator-associated pneumonia than the clinical-based score (i.e. the Clinical Pulmonary Infection Score) [55].

\section{Pneumothorax}

Pneumothorax is the interposition of gas between visceral and parietal pleura. LU findings in pneumothorax are A-lines and the absence of lung sliding, B-lines and visualisation of a lung point [56]. The lung point corresponds to the area on the chest wall adjacent to the pneumothorax where the respiratory movement of the lung reappears. This transition between sliding and non-sliding pattern represents the limit of the pneumothorax and is a measure of its extension and volume [57].

In trauma patients in the emergency department, LU performs better than CXR in diagnosing pneumothoraces and can also detect the presence of occult pneumothoraces $[58,59]$. A CXR is routinely requested after central venous catheter placement to exclude the presence of an iatrogenic pneumothorax. LU combined with contrast-enhanced ultrasonography has high accuracy in excluding both a pneumothorax and catheter malposition $[60,61]$, with a significant reduction in the mean time required for the examination [62]. In addition, LU can be used to exclude a pneumothorax, as an alternative to CXR, after chest tube removal [63].

\section{Pleural effusion}

LU can reliably identify free pleural effusion that appears as a dependent echo-free space between the parietal and visceral pleura [64]. LU may also allow semi-quantitative, clinically useful estimations of effusion volume. The expiratory interpleural distance measured at the thoracic base with ultrasonography has been proven to correlate with the fluid volume [65]; LU is able to detect pleural effusion in different clinical conditions, irrespective of the underlying disorder [66-69].

Ultrasound-guided thoracentesis in patients receiving mechanical ventilation reduces the risk of pneumothorax to $<1 \%$ [70].

Miniaturised ultrasound systems such as hand-carried ultrasound imagers are now available. These systems allow a more prompt bedside diagnosis and immediate therapeutic measures, and could provide a helpful technique for the primary assessment of pleural effusions [71].

\section{Computed tomography}

The studies on CT used to prepare this statement are listed in table 3. CT scanning is frequently performed in critically ill patients, either at admission or later in cases of worsening respiratory failure. A retrospective analysis conducted in medical critically ill patients reported that a CT scan was performed in $11.5 \%$ of all patients admitted to the ICU [72]. Consolidations, pleural effusions and parenchymal abnormalities were each present in more than one-fifth of the patients. The most common CT findings included consolidations (46\%), other parenchymal abnormalities (29\%) and pleural effusions (35\%). Clinical changes clearly linked to chest CT were observed in $24 \%$ of the patients [72].

\section{ARDS}

Description of the findings

Since the first description of chest CT in ARDS, the described disease patterns have included ground glass opacifications, parenchymal distortion, areas of consolidation, and reticular and linear opacities [73]. These alterations detected by CT scan are significantly related to the impairment of gas exchange and to the lung injury score [74]. ARDS patients are characterised by a lower end-expiratory lung gas volume and an increase in lung oedema with a typical diffuse or patchy distribution of attenuation in the lung [75-77]. However, owing to the inhomogeneous distribution of the disease, a single-slice CT, compared to an overall lung study, cannot accurately describe the amount of reopening of collapsed lung regions due to PEEP changes [78]. An important technical issue with CT is the spatial resolution. VIEIRA et al. [79] demonstrated that low spatial resolution CT can underestimate the degree of hyperinflation due to PEEP compared to high spatial resolution CT, particularly when the lung morphology has a focal loss of aeration. 
TABLE 3 Studies included on CT

\begin{tabular}{|c|c|c|c|c|c|c|}
\hline Disease & Reference & First author & Aim & Subjects & Study design & Main results \\
\hline ARDS & [72] & Awerbuch E & To evaluate the diagnostic and clinical impact of CT & 134 & Retrospective & Up to one-quarter of patients had clinical changes \\
\hline ARDS & [73] & Owens CM & $\begin{array}{l}\text { To compare morphological CT abnormalities with } \\
\text { severity of lung injury score }\end{array}$ & 8 & Prospective & $\begin{array}{l}\text { Extent of CT abnormalities correlated with lung injury } \\
\text { score }\end{array}$ \\
\hline ARDS & [74] & Bombino M & To compare $\mathrm{CT}$ and $\mathrm{CXR}$ with clinical data & 17 & Prospective & $\begin{array}{l}\mathrm{CT} \text { and CXR scores were related to the degree of gas } \\
\text { exchange impairment }\end{array}$ \\
\hline ARDS & [75] & Puybasset L & $\begin{array}{l}\text { To compare CT distribution of gas and tissue } \\
\text { analysis in ARDS and healthy subjects }\end{array}$ & 82 & Prospective & $\begin{array}{l}\text { Different lung morphologies corresponded to different } \\
\text { distributions of gas within the lung }\end{array}$ \\
\hline ARDS & [76] & Patroniti N & $\begin{array}{l}\text { To compare helium dilution technique with CT to } \\
\text { assess lung gas volume in patients with ARDS }\end{array}$ & 21 & Prospective & $\begin{array}{l}\text { Helium dilution technique showed good agreement } \\
\text { with CT }\end{array}$ \\
\hline ARDS & [77] & Patroniti N & $\begin{array}{l}\text { To compare CT and indocyanine green dye double } \\
\text { dilution technique for measurement of } \\
\text { pulmonary oedema in ARDS }\end{array}$ & 14 & Prospective & $\begin{array}{l}\text { Estimation of oedema with indocyanine green showed } \\
\text { good correlation and reproducibility with CT }\end{array}$ \\
\hline ARDS & [78] & Lu Q & $\begin{array}{l}\text { To assess PEEP changes in single- or } \\
\text { three-section, or whole lung CT }\end{array}$ & 39 & Retrospective & Single- and three-section differed from whole lung $\mathrm{CT}$ \\
\hline ARDS & [79] & Vieira SRR & $\begin{array}{l}\text { To compare pulmonary hyperinflation measured by } \\
\text { low and high spatial resolution } \mathrm{CT}\end{array}$ & 30 & Prospective & $\begin{array}{l}\text { In ARDS accurate estimation of lung hyperinflation on } \\
\text { CT required high spatial resolution }\end{array}$ \\
\hline ARDS & [80] & Reske AW & To evaluate the ratio between $\mathrm{PaO}_{2} / \mathrm{FiO}_{2}$ and shunt & 71 & Prospective & $\begin{array}{l}\text { Logarithmic } \mathrm{PaO}_{2} / \mathrm{FiO}_{2} \text { allowed estimation of CT shunt } \\
\text { and its changes }\end{array}$ \\
\hline ARDS & [81] & Caironi P & To assess a standardised low PEEP strategy & 148 & Retrospective & $\begin{array}{l}\text { The } \mathrm{PaO}_{2} / \mathrm{FiO}_{2} \text { computed at } 5 \mathrm{cmH}_{2} \mathrm{O} \text { of } \mathrm{PEEP} \text { accurately } \\
\text { reflected the lung injury severity and recruitability }\end{array}$ \\
\hline ARDS & [82] & Rouby JJ & $\begin{array}{l}\text { To assess differences in lung morphology with } \\
\text { different lung mechanics and outcome }\end{array}$ & 71 & Prospective & $\begin{array}{l}\text { A severity score based on } \mathrm{CT} \text { lung morphology } \\
\text { accurately identified patients with the most severe } \\
\text { forms of ARDS }\end{array}$ \\
\hline ARDS & [83] & Stelter $\mathrm{L}$ & $\begin{array}{l}\text { To evaluate CT findings in patients with sepsis and } \\
\text { ARDS }\end{array}$ & 36 & Prospective & $\begin{array}{l}\text { A CT scoring system based on pulmonary findings was } \\
\text { related to the outcome }\end{array}$ \\
\hline ARDS & [84] & Lazoura 0 & $\begin{array}{l}\text { To correlate CT morphology with clinical severity } \\
\text { and outcome }\end{array}$ & 33 & Retrospective & $\begin{array}{l}\text { A greater extent of airspace disease was associated } \\
\text { with higher clinical severity }\end{array}$ \\
\hline ARDS & [85] & Simon M & To assess clinical utility of CT & 204 & Retrospective & $\begin{array}{l}\text { CT yielded useful information for diagnosis, prognosis } \\
\text { and alternative diagnosis in ARDS patients }\end{array}$ \\
\hline ARDS & [86] & Chiumello D & $\begin{array}{l}\text { To investigate if low-dose CT can provide accurate } \\
\text { quantitative and visual anatomical results }\end{array}$ & 45 & Prospective & $\begin{array}{l}\text { Low-dose CT showed good agreement with } \\
\text { conventional CT both for quantitative and visual } \\
\text { anatomical results }\end{array}$ \\
\hline ARDS & [87] & Klapsing P & $\begin{array}{l}\text { To investigate an automatic software programme } \\
\text { for quantitative lung analysis }\end{array}$ & 10 & Prospective & $\begin{array}{l}\text { Automatic software computation allowed accurate } \\
\text { computation }\end{array}$ \\
\hline ARDS & [88] & Miller PR & $\begin{array}{l}\text { To identify high-risk patients according to } \\
\text { pulmonary contusion volume }\end{array}$ & 49 & Prospective & $\begin{array}{l}\text { Contusion volume on chest CT was predictive for ARDS } \\
\text { development }\end{array}$ \\
\hline ARDS & [89] & Reske AW & $\begin{array}{l}\text { To evaluate quantitative } \mathrm{CT} \text { in post-traumatic lung } \\
\text { dysfunction }\end{array}$ & 78 & Prospective & $\begin{array}{l}\text { Quantitative CT might help to discriminate atelectasis } \\
\text { from consolidation }\end{array}$ \\
\hline ARDS & [90] & Chiumello D & $\begin{array}{l}\text { To assess the effect of pleural effusion on } \\
\text { respiratory mechanics, gas exchange and lung } \\
\text { recruitability }\end{array}$ & 179 & Prospective & $\begin{array}{l}\text { Pleural effusion was of modest entity and did not } \\
\text { affect respiratory system elastance }\end{array}$ \\
\hline ARDS & [91] & Gattinoni L & To assess CT changes in early and late ARDS & 81 & Prospective & Lung structure markedly changed with ARDS duration \\
\hline ARDS & [92] & Treggiari MM & $\begin{array}{l}\text { To investigate prevalence/distribution of air cysts } \\
\text { and bronchiectasis }\end{array}$ & 21 & Retrospective & $\begin{array}{l}\text { A predominant localisation of lesions in better } \\
\text { ventilated areas (non-dependent) }\end{array}$ \\
\hline ARDS & [93] & Burnham EL & $\begin{array}{l}\text { To determine the relationship between pulmonary } \\
\text { dysfunction and high-resolution CT }\end{array}$ & 89 & Prospective & $\begin{array}{l}\text { Among survivors, high-resolution CT findings } \\
\text { correlated with quality of life }\end{array}$ \\
\hline
\end{tabular}


TABLE 3 Continued

\begin{tabular}{|c|c|c|c|c|c|c|}
\hline Disease & Reference & First author & Aim & Subjects & Study design & Main results \\
\hline ARDS & [94] & Nobauer IM & $\begin{array}{l}\text { To evaluate changes in high-resolution CT 6- } \\
10 \text { months after ARDS }\end{array}$ & 15 & Prospective & $\begin{array}{l}\text { ARDS frequently resulted in fibrotic changes in the } \\
\text { lung, particularly in the ventral regions }\end{array}$ \\
\hline ARDS & [95] & Masclans JR & $\begin{array}{l}\text { To evaluate the quality of life in survivors of ARDS } \\
\text { and related CT changes }\end{array}$ & 38 & Prospective & $\begin{array}{l}6 \text { months after ARDS, there were mild radiological } \\
\text { abnormalities in } 76 \% \text { of patients }\end{array}$ \\
\hline ARDS & [96] & Kim SJ & $\begin{array}{l}\text { To determine if outcome differs between } \\
\text { pulmonary and extrapulmonary ARDS }\end{array}$ & 29 & Retrospective & $\begin{array}{l}\text { Pulmonary lesions were more extensive in pulmonary } \\
\text { compared to non-pulmonary ARDS }\end{array}$ \\
\hline ARDS & [97] & Cressoni M & $\begin{array}{l}\text { To assess the relationship between lung } \\
\text { recruitability and pressure to overcome the } \\
\text { compression forces }\end{array}$ & 51 & Prospective & $\begin{array}{l}\text { Lung recruitability was not related to the pressure to } \\
\text { overcome compression forces }\end{array}$ \\
\hline ARDS & [98] & Puybasset L & To evaluate PEEP changes and lung morphology & 71 & Retrospective & $\begin{array}{l}\text { PEEP effects were more related to lung morphology } \\
\text { than the cause of lung injury }\end{array}$ \\
\hline ARDS & [99] & Constantin J-M & $\begin{array}{l}\text { To determine if differences in lung morphology } \\
\text { predict the response to recruitment manoeuvres }\end{array}$ & 19 & Prospective & $\begin{array}{l}\text { Lung morphology predicted response to recruitment; } \\
\text { focal lung morphology was at high risk for } \\
\text { hyperinflation with recruitment manoeuvre }\end{array}$ \\
\hline ARDS & [100] & Chiumello D & To evaluate the effects of body mass index in ARDS & 101 & Retrospective & $\begin{array}{l}\text { Obese patients with ARDS had similar chest wall } \\
\text { elastance and lung recruitability compared to } \\
\text { non-obese ARDS patients }\end{array}$ \\
\hline ARDS & [101] & Cressoni M & $\begin{array}{l}\text { To assess the amount of lung recruitability and } \\
\text { opening and closing }\end{array}$ & 33 & Prospective & $\begin{array}{l}\text { PEEP up to } 25 \mathrm{~cm} \mathrm{H}_{2} \mathrm{O} \text { and plateau pressure up to } \\
30 \mathrm{~cm} \mathrm{H}_{2} \mathrm{O} \text { were not adequate to keep the lung open }\end{array}$ \\
\hline ARDS & [102] & Cressoni M & To quantify lung inhomogeneity & 148 & Retrospective & $\begin{array}{l}\text { Lung inhomogeneity was related to disease severity } \\
\text { and mortality }\end{array}$ \\
\hline ARDS & [103] & Chiumello D & $\begin{array}{l}\text { To determine if bedside PEEP selection is related } \\
\text { to lung recruitability }\end{array}$ & 51 & Prospective & $\begin{array}{l}\text { Oxygenation based method provided PEEP related to } \\
\text { lung recruitability }\end{array}$ \\
\hline ARDS & [104] & Constantin J-M & To compare two recruitment manoeuvres in ARDS & 19 & Prospective & $\begin{array}{l}\text { Extended sigh promoted higher alveolar recruitment } \\
\text { and oxygenation compared to CPAP RM }\end{array}$ \\
\hline ARDS & [105] & Galiatsou & $\begin{array}{l}\text { To quantify lung volume changes during prone } \\
\text { position }\end{array}$ & 21 & Prospective & $\begin{array}{l}\text { Prone position recruited significantly more lung } \\
\text { compared to recruitment manoeuvre }\end{array}$ \\
\hline ARDS & [106] & Lu Q & $\begin{array}{l}\text { To evaluate the effects of exogenous surfactant on } \\
\text { pulmonary aeration in patients with ARDS }\end{array}$ & 20 & Prospective & $\begin{array}{l}\text { Surfactant administration induced an improvement in } \\
\text { lung aeration of poorly and non-aerated lung } \\
\text { regions }\end{array}$ \\
\hline ARDS & [107] & Lu Q & $\begin{array}{l}\text { To compare PV curves and CT during } \\
\text { PEEP-induced lung recruitment }\end{array}$ & 19 & Prospective & $\begin{array}{l}\text { Alveolar recruitment assessed by CT and PV curve } \\
\text { were strongly correlated but with very high limits of } \\
\text { agreements }\end{array}$ \\
\hline ARDS & [108] & Yoshida T & $\begin{array}{l}\text { To compare airway pressure release ventilation } \\
\text { compared to PSV on lung atelectasis }\end{array}$ & 18 & Retrospective & $\begin{array}{l}\text { Airway pressure released ventilation resulted in better } \\
\text { lung aeration compared to PSV }\end{array}$ \\
\hline ARDS & [109] & Varpula $T$ & $\begin{array}{l}\text { To compare airway pressure release ventilation } \\
\text { compared to PSV on lung atelectasis and gas } \\
\text { distribution }\end{array}$ & 23 & Retrospective & $\begin{array}{l}\text { No differences in airway pressure release ventilation } \\
\text { or PSV on CT characteristics }\end{array}$ \\
\hline AHF & [110] & Saguel B & $\begin{array}{l}\text { To compare } \mathrm{CT} \text { estimation of cardiac preload and } \\
\text { pulmonary hydration in predicting volume status }\end{array}$ & 30 & Prospective & $\begin{array}{l}\text { CT estimation of end diastolic volume index and } \\
\text { extravascular lung water were not accurate in } \\
\text { predicting volume status }\end{array}$ \\
\hline AHF & [111] & Zhang $\mathrm{F}$ & $\begin{array}{l}\text { To evaluate quantitative CT analysis to measure } \\
\text { pulmonary oedema }\end{array}$ & 10 & Prospective & $\begin{array}{l}\text { Acceptable agreement between CT analysis and } \\
\text { thermodilution }\end{array}$ \\
\hline AHF & [112] & Vergani G & $\begin{array}{l}\text { To compare quantitative CT analysis in cardiogenic } \\
\text { pulmonary oedema and ARDS }\end{array}$ & 80 & Prospective & $\begin{array}{l}\text { Similar presence of ground glass and different } \\
\text { airspace consolidation regions }\end{array}$ \\
\hline Pneumonia & [113] & Syriala H & & 47 & Prospective & $\mathrm{CT}$ was more sensitive than $\mathrm{CXR}$ \\
\hline
\end{tabular}




\begin{tabular}{|c|c|c|c|c|c|c|}
\hline Disease & Reference & First author & Aim & Subjects & Study design & Main results \\
\hline & & & $\begin{array}{l}\text { To compare CT with CXR in the diagnosis of } \\
\text { pneumonia }\end{array}$ & & & \\
\hline Pneumonia & [114] & Gruden JF & To compare CT with CXR in AIDS patients & 33 & Prospective & CT was more sensitive than CXR \\
\hline Pneumonia & [115] & Claessens Y-E & $\begin{array}{l}\text { To compare } \mathrm{CT} \text { with } \mathrm{CXR} \text { in the diagnosis of } \\
\text { community-acquired pneumonia }\end{array}$ & 319 & Prospective & CT was more sensitive than CXR \\
\hline Pneumonia & [116] & Hockstein NG & To compare CT with electronic nose sensor & 33 & Prospective & $\begin{array}{l}\text { Acceptable agreement between CT and nose sensor } \\
\text { for pneumonia }\end{array}$ \\
\hline COPD & [117] & Nieskowska A & $\begin{array}{l}\text { To assess the regional distribution of inflation in } \\
\text { COPD }\end{array}$ & 32 & Prospective & PEEP significantly increased lung overinflation \\
\hline COPD & [118] & Bahloul M & $\begin{array}{l}\text { To assess the incidence and outcome of pulmonary } \\
\text { embolism in COPD }\end{array}$ & 131 & Retrospective & $\begin{array}{l}\text { Higher mortality and length of stay in COPD patients } \\
\text { with an acute exacerbation and pulmonary } \\
\text { embolism }\end{array}$ \\
\hline Pneumothorax & [119] & Lichtenstein DA & $\begin{array}{l}\text { To compare CT with LU in the diagnosis of occult } \\
\text { pneumothorax }\end{array}$ & 200 & Retrospective & LU might decrease the need for $\mathrm{CT}$ \\
\hline Pneumothorax & [120] & Soldati G & $\begin{array}{l}\text { To compare CT with LU in the diagnosis of occult } \\
\text { pneumothorax }\end{array}$ & 109 & Prospective & LU might decrease the need for $\mathrm{CT}$ \\
\hline Pneumothorax & [121] & Xirouchaki N & To compare CT with LU and CXR & 42 & Prospective & LU could be an alternative to CT \\
\hline $\begin{array}{l}\text { Pleural } \\
\text { effusion }\end{array}$ & [122] & Remerand F & $\begin{array}{l}\text { To assess the accuracy of LU to measure pleural } \\
\text { effusion }\end{array}$ & 58 & Prospective & $\begin{array}{l}\text { The multiplane LU approach estimated pleural } \\
\text { effusion volume better than the conventional } \\
\text { technique }\end{array}$ \\
\hline
\end{tabular}

$\mathrm{CT}$ : computed tomography; ARDS: acute respiratory distress syndrome; CXR: chest X-ray; PEEP: positive end-expiratory pressure; $\mathrm{PaO}_{2}$ : arterial oxygen tension; FiO ${ }_{2}$ : fraction of inspired oxygen; CPAP: continuous positive airway pressure; RM: remote monitoring; PSV: pressure support ventilation; AHF: acute heart failure; COPD: chronic obstructive pulmonary disease; LU: lung ultrasound. 
ARDS is characterised by different levels of hypoxaemia due to different amounts of non-aerated lung regions (i.e. alveolar shunt), which can be precisely quantified by CT. The logarithmically transformed arterial oxygen tension $\left(\mathrm{PaO}_{2}\right)$ /inspiratory oxygen fraction $\left(\mathrm{FiO}_{2}\right)$ due to pure oxygen ventilation allows CT shunt to be estimated [80]. According to the recent Berlin definition of ARDS that proposed three exclusive categories according to the degree of hypoxaemia, a PEEP of $5 \mathrm{cmH}_{2} \mathrm{O}$ should be applied to stratify patients at intensive care admission. This relatively low PEEP level is accurate in predicting the severity of hypoxaemia and the recruitability of the lung compared to higher PEEP levels [81]. At $5 \mathrm{cmH}_{2} \mathrm{O}$ of PEEP the potential for lung recruitment is significantly different according to each ARDS category of the Berlin definition, being two and three times higher in patients with moderate and severe ARDS compared to mild ARDS [81], suggesting that low PEEP levels should be applied upon intensive care admission to stratify patients according to the severity of disease.

Patients with diffuse attenuations have a higher mortality rate compared to lobar attenuations [82]. In one study, up to $50 \%$ of patients with sepsis and ARDS had a CT scan score higher than that of survivors and fewer ground glass opacities [83]. Pulmonary findings on CT did not allow discrimination between a pulmonary and extrapulmonary focus of infection [83].

In a study of patients with ARDS caused by H1N1 influenza, the amounts of total lung consolidation and ground glass opacity were not different. However, the total lung consolidation significantly increased, whereas total lung ground glass opacity decreased from the anterior towards the posterior. The total lung disease was significantly higher in patients who required extracorporeal membrane oxygenation (ECMO) compared to those who did not require ECMO [84]. Chest CT has substantially changed the understanding and management of patients with ARDS. SIMON et al. [85] reported that chest CT affected treatment in $27 \%$ of cases, in particular resulting in alteration in antibiotic therapy (8\%), drainage of pleural fluid (8\%) and modification in antimycotic therapy (4\%). Major disadvantages of CT are that the patient has to be transported to the radiological department and the radiation exposure. Chiumello et al. [86] demonstrated that low-dose CT has a high agreement with conventional CT for quantitative analysis in ARDS patients. The current standard technique for quantitative CT scan analysis is based on a manual lung segmentation, which is time-consuming and depends on the skill of the operator. Klapsing et al. [87] reported very good precision for an automatic lung segmentation software program compared to manual segmentation. This automatic lung CT segmentation was able to reduce the processing time by $>99 \%$.

Trauma patients are at risk for developing ARDS, and CT could be used to detect possible lung and heart disease [85]. In a study of chest trauma patients with pulmonary contusion, the volume of the contusion was related to higher risk of ARDS [88]. Quantitative CT scan analysis offers the possibility of computing the total lung weight and could be used to discriminate lung atelectasis from consolidation. In a group of trauma patients with ARDS, $60 \%$ of the patients had a lung weight volume similar to that of trauma patients without ARDS, suggesting a higher amount of atelectasis compared to consolidation [89].

In the early phase of ARDS, the amount of pleural effusion is quite modest (an average of $340 \mathrm{~mL}$ ) and does not affect the respiratory system elastance, amount of lung collapse or degree of oxygenation [90].

Treatment effect

Chest CT has been used to determine complications of mechanical ventilation or in the follow-up of ARDS patients. Late ARDS has a significantly higher incidence of pneumothoraces and number of bullae compared to early ARDS [91]. TREGGIARI et al. [92] performed chest CT in ARDS patients on prolonged ventilation (interval between ARDS and CT scan $22 \pm 19$ days). They found that development of air cysts and bronchiectasis in ventilated patients with ARDS mainly occurred in non-dependent lung regions and severity correlated with peak pressures.

Although the mortality rate of ARDS patients has significantly decreased through the years, it still ranges between $40 \%$ and $50 \%$, with surviving patients having a significant reduction in their quality of life. In a study of acute lung injury survivors, decrements in quality of life attributable to pulmonary dysfunction were strongly associated with higher radiological scores [93]. In a small study, 87\% of patients with ARDS (13 out of 15) exhibited fibrotic changes in the lung, in particular in the ventral parts, as assessed by high-resolution CT [94]. A significant correlation was found between the severity of ARDS and the severity of CT findings. In a subsequent study [95], lung abnormalities were found on high-resolution CT in $75 \%$ of patients 6 months after recovery. A reticular pattern was the most frequent finding. A predominance for the ventral parts was noted in $37 \%$ of the patients. KIM et al. [96] found that patients with pulmonary ARDS had more severe lung sequelae on chest CT after $20 \pm 12$ months compared to patients with extrapulmonary ARDS.

CT has previously been used to evaluate or predict the response to PEEP changes and to recruitment manoeuvres in patients with ARDS [97]. Analysing lung recruitability as the decrease in non-aerated tissue 
from 5 to $45 \mathrm{cmH}_{2} \mathrm{O}$ of PEEP, an average of $15 \%$ of the total lung tissue was found to be unrelated to the amount of compressive forces (lung oedema and characteristics of the chest wall). This suggests that the amount of PEEP required to keep the lung open is independent of the amount of tissue which should be kept open, and that factors such as the distribution of oedema within the lung being mainly intra- or extra-alveolar and the nature of the disease play an important role [97]. In patients with diffuse attenuation, PEEP induced significant alveolar recruitment without over-distension; in patients with lobar CT attenuation, PEEP induced mild alveolar recruitment with over-distension of the already inflated lung regions [98]. Patients with focal ARDS at zero end-expiratory pressure are at increased risk of hyperinflation during recruitment manoeuvres and are less likely to show recruitment compared to patients with a non-focal lung morphology [99]. The effect of body mass index in ARDS is not associated with significant differences in lung recruitability and respiratory mechanics [100]. In addition, according to protective ventilation, between $10 \%$ and $30 \%$ of the potentially recruitable lung always remains closed. Furthermore, increasing PEEP up to $15 \mathrm{cmH}_{2} \mathrm{O}$ does not prevent the cyclic lung tissue opening and closing [101].

In an ARDS lung the distribution of the lesions (consolidations and atelectases) is inhomogeneous, promoting a regional increase in transpulmonary pressure, acting as stress raiser. Thus, a safe transpulmonary pressure could become harmful (i.e. reaching high levels) in the presence of stress raisers. It has been found that the extent of lung inhomogeneity increases with the severity of ARDS; increasing PEEP significantly decreases the amount of lung inhomogeneity [102].

Randomised clinical trials comparing high and low PEEP values in ARDS have not find any difference in the outcome, probably owing to several factors not being taken into account, such as the potential for lung recruitability, the amount of oedema or disease severity. When different PEEP selection methods (based on lung mechanics, oesophageal pressure and oxygenation) were compared according to lung recruitability, the oxygenation method provided higher PEEP levels (i.e. higher PEEP in patients with higher recruitability) [103].

Constantin et al. [104] compared two recruitment manoeuvres, CPAP with $40 \mathrm{cmH}_{2} \mathrm{O}$ for $40 \mathrm{~s}$ versus PEEP maintained at $10 \mathrm{cmH}_{2} \mathrm{O}$ above the lower inflection point of the pressure volume curve for $15 \mathrm{~min}$. Although the increase in oxygenation was different, lung recruitment estimated by CT was significantly lower with the CPAP manoeuvre. GALIATSOu et al. [105] demonstrated that pronation in patients with ARDS recruited lung tissue in dependent lung areas and reversed overinflation of the ventral areas. Surfactant deficiency in ARDS also contributes to alveolar derecruitment. The administration of surfactant in mechanically ventilated patients is associated with a significant increase in the volume of gas in poorly/ non-aerated lung areas and a significant increase in tissue volume in normally aerated lung areas [106]. Concerning the estimation of lung recruitment with $\mathrm{CT}$ or the pressure volume curve, they are well related despite having very large limits of agreement [107].

Two studies have used CT to compare different ventilator modes on lung aeration in patients with ARDS $[108,109]$. The first found that airway pressure release ventilation significantly decreases the amount of atelectasis and increases the normally aerated lung volume compared to pressure support ventilation [108]. By contrast, a latter study failed to identify any differences between airway pressure release ventilation and pressure support ventilation from admission to day 7 [109].

\section{Acute heart failure}

Practical issues limit the application of CT in the acute phase for the diagnosis of acute cardiogenic pulmonary oedema. In a retrospective study, CT markers for acute pulmonary oedema (i.e. engorged peripheral pulmonary vessels, thickening of inter- and intra-lobular septa, ground glass opacities and consolidations) were compared with transpulmonary thermodilution technique variables [110]. The authors concluded that haemodynamic parameters obtained with transpulmonary thermodilution cannot be accurately estimated by CT. In a small study in ARDS patients, a good correlation was found between transpulmonary thermodilution and CT markers for pulmonary oedema [111]. Patients with acute pulmonary oedema presented with a similar amount of ground glass attenuation and a lower amount of airspace consolidation [112].

\section{Pneumonia}

CT is more sensitive than CXR in detecting pulmonary infiltrates in patients with clinical suspicion of pneumonia $[113,114]$. Similarly, in patients admitted to the emergency department with clinically suspected community-acquired pneumonia, CT modified the likelihood of diagnosing community-acquired pneumonia in $58 \%$ of cases [115].

In addition, CT can also provide a detailed morphological description of patients with ventilatorassociated pneumonia. CT scans of a group of patients with ventilator-associated pneumonia at diagnosis 
and at day 7 of antimicrobial therapy were characterised by the presence of intraparenchymal and subpleural rounded CT attenuations disseminated within the upper and lower lobes, with consolidations of the lower and upper lobes [54]. Patients who responded successfully to antimicrobial therapy showed predominant disappearance of the rounded opacities, whereas antibiotic failures correlated with new onset of rounded opacities within the lungs. A significant correlation was found between chest CT diagnosis of pneumonia and electronic nose sensor of the expired gases, a new promising adjunct tool for the diagnosis of pneumonia [116].

\section{COPD}

Patients with severe acute exacerbation of COPD, due to infection or cardiac failure, frequently require mechanical ventilation with PEEP to improve oxygenation and to reduce the work of breathing. However, the increase in PEEP is associated with an increase in lung volume with possible risks of overinflation [117].

In addition, COPD patients are at increased risk of developing pulmonary thromboemboli. During a 5 -year follow-up from an acute exacerbation of COPD, 17\% of patients developed pulmonary embolism; the ICU length of stay and mortality were significantly higher in patients with pulmonary embolism [118].

\section{Pneumothorax}

CT is commonly used for the diagnosis of pneumothorax. It is known that supine CXR is not sensitive for the diagnosis of pneumothorax in non-ICU patients $[119,120]$.

Very few studies have compared conventional CXR with CT in ICU patients. However, in a prospective study of 42 ICU patients, none of the eight pneumothoraces diagnosed by CT were seen with CXR [121].

\section{Pleural effusion}

The quantitative computation of pleural effusion with whole chest CT has been demonstrated to significantly relate to the amount of pleural effusion computed with LU using a multiplanar ultrasound approach considering the cephalocaudal extension and the area measured at mid length [122].

\section{PET}

The studies on PET used to prepare this statement are listed in table 4. PET provides a functional examination, detecting the presence of a radioactive tracer that is usually administered to patients linked to a biological molecule. One of the most common tracers is [18F]-2-fluoro-2-deoxy-D-glucose (18FDG). In the presence of an inflammatory status there is an increase in cellular metabolism and glucose consumption, mainly linked to neutrophilic activity.

\section{ARDS}

ARDS lung is characterised by an increase in pulmonary vascular permeability in addition to abnormalities in gas exchange [1]. Pulmonary vascular permeability can be assessed by the pulmonary transcapillary escape rate for transferrin with PET (PTCER), which evaluates the protein flux between the pulmonary intravascular and extravascular compartments. ARDS and pneumonia patients have been found to present with a significantly higher PTCER than heart failure patients and healthy subjects [123]. In a group of pneumonia patients, PTCER was also higher in the regions contralateral to focal pneumonia [123]. ARDS in the early phases has been found to have a higher PTCER compared to the late phases [124], which is still higher than that of healthy subjects [124].

The current lung ARDS model, extensively explained by CT, indicates that regions of normal aeration coexist with poorly and non-aerated lung regions, and that lung densities are mainly located in the dependent lung regions [125]. Similarly, PET shows a significant increase in lung density in dorsal compared to ventral lung regions, with a higher amount of the same lung regions compared to healthy subjects [126]. Surprisingly, no difference has been found in the PTCER distribution between the dorsal and ventral lung regions. Despite a lack of difference between the ventral and dorsal regions, PTCER was not uniformly distributed in ARDS patients, thereby suggesting a possible blood-borne delivery of injurious agents to the lung [126].

Combining PET and CT with 18FDG it is possible to assess the distribution and magnitude of inflammation within the lung. Different approaches have been proposed, such as the simple static model that measures the standardised uptake volume, dynamic models that analyse the spectral analysis filter, and the Patlak analysis. In a comparison of the static and dynamic models in ARDS patients, the dynamic model provided a better description of lung inflammation [127]. In ARDS patients, the metabolic activity of the lungs was significantly higher than in healthy subjects, and did not correlate with the mean lung density or with the relative weight of either non-aerated or normally aerated tissue [128]. The inflammation activity negatively correlated with oxygenation levels. In the normally aerated tissue the 


\begin{tabular}{|c|c|c|c|c|c|c|}
\hline Disease & Reference & First author & Aim & Subjects & Study design & Main results \\
\hline ARDS & [123] & Kaplan JD & To measure pulmonary vascular permeability & 43 & Prospective & ARDS and pneumonia had higher PTCER \\
\hline ARDS & [124] & Calandrino FS & To measure pulmonary vascular permeability & 27 & Prospective & Early versus late ARDS had higher PTCER \\
\hline ARDS & [125] & Sandiford P & $\begin{array}{l}\text { To measure regional distribution of vascular } \\
\text { permeability }\end{array}$ & 8 & Observational & No difference in the distribution of PTCER \\
\hline ARDS & [126] & Grecchi E & $\begin{array}{l}\text { To investigate PET static and dynamic model } \\
\text { analysis }\end{array}$ & 11 & Observational & Dynamic model better described lung inflammation \\
\hline ARDS & [127] & Bellani G & To investigate inflammation distribution & 10 & Observational & $\begin{array}{l}\text { Lung inflammation was diffusely distributed within the } \\
\text { lung }\end{array}$ \\
\hline ARDS & [128] & Bellani G & $\begin{array}{l}\text { To assess gas volume changes and metabolic } \\
\text { activity }\end{array}$ & 13 & Observational & $\begin{array}{l}\text { No difference in lung inflammation between recruited- } \\
\text { derecruited and collapsed regions }\end{array}$ \\
\hline ARDS & [129] & Cressoni M & $\begin{array}{l}\text { To determine size and location of lung } \\
\text { inhomogeneity and inflammation }\end{array}$ & 20 & Observational & $\begin{array}{l}\text { Different regional distribution of inhomogeneity and } \\
\text { inflammation }\end{array}$ \\
\hline AHF & [130] & Schuster DP & To assess perfusion distribution & 21 & Observational & Similar pulmonary blood flow among the groups \\
\hline Pneumonia & [131] & Chen DL & $\begin{array}{l}\text { To investigate the relationship between lung } \\
\text { inflammation and lung function }\end{array}$ & 27 & Observational & $\begin{array}{l}\text { Patients with cystic fibrosis had higher inflammation } \\
\text { compared to healthy subjects }\end{array}$ \\
\hline Pneumonia & [132] & Nusair S & $\begin{array}{l}\text { To assess possible use of PET in interstitial lung } \\
\text { disease }\end{array}$ & 21 & Observational & $\begin{array}{l}\text { No difference in tracer uptake between patients with } \\
\text { different interstitial lung diseases }\end{array}$ \\
\hline Pneumonia & [133] & Umeda Y & $\begin{array}{l}\text { To assess the degree of inflammation and } \\
\text { disease progression }\end{array}$ & 50 & Observational & $\begin{array}{l}\text { Possible use in analysis of disease progression and } \\
\text { response to therapy }\end{array}$ \\
\hline COPD & [134] & Vidal Melo MF & To assess ventilation distribution in COPD & 12 & Observational & High heterogeneity of ventilation distribution in COPD \\
\hline Pleural effusion & [135] & Nakajima R & $\begin{array}{l}\text { To discriminate benign from malignant pleural } \\
\text { effusion }\end{array}$ & 79 & Retrospective & $\begin{array}{l}\text { Good accuracy in discriminating benign from malignant } \\
\text { pleural effusion }\end{array}$ \\
\hline Pleural effusion & [136] & Duysink BC & $\begin{array}{l}\text { To discriminate benign from malignant pleural } \\
\text { effusion }\end{array}$ & 36 & Retrospective & $\begin{array}{l}\text { Good accuracy in discriminating benign from malignant } \\
\text { pleural effusion }\end{array}$ \\
\hline
\end{tabular}

PET: positron emission tomography; ARDS: acute respiratory distress syndrome; PTCER: pulmonary transcapillary escape rate; AHF: acute heart failure; COPD: chronic obstructive pulmonary disease. 
metabolic activity was significantly higher, up to seven times, than that of healthy subjects. Additionally, lung inflammation was very differently distributed considering the distribution of inflation (from non-inflated to well-inflated regions) [128].

The same authors analysed the relationship between gas volume changes induced by tidal ventilation, from end expiration to end inspiration, and pulmonary inflammation [129]. The lung regions undergoing intra-tidal recruitment and de-recruitment during tidal breathing had similar lung inflammation to the collapsed ones. Airway pressure positively correlated with lung inflammation [129].

Owing to the greater distribution of lung oedema in the dorsal regions, greater lung inhomogeneity of lung parenchyma may be present along the sternum-vertebral axis. Concerning the distribution of lung inhomogeneity and inflammation within the lung, the amount of lung inflammation and inhomogeneity has been shown to increase from mild to severe ARDS [130]. In that study, the homogeneous lung compartment with normal PET signal was mainly composed of well-inflated tissue and was located in the ventral regions. By contrast, the inhomogeneous compartment with high PET signal was composed of non- or poorly inflated tissue and located in the dorsal regions. The homogeneous lung compartment with high PET signal comprised mixed lung aeration from non-inflated to well-inflated regions and was similarly distributed within the lung [130].

\section{Acute heart failure}

Pulmonary hypertension, which is frequent in ARDS patients, has been associated with pulmonary vasoconstriction in response to hypoxia, which could redistribute pulmonary blood flow within the sick lung. The ventral to dorsal regional distribution of pulmonary blood flow has been analysed in a group of patients with pulmonary lung oedema and in healthy subjects [131]. Although the amount of lung water concentration was significantly higher in ARDS and cardiogenic pulmonary oedema, the regional distribution of pulmonary blood flow was similar among ARDS and healthy subjects [131].

\section{Pneumonia}

By analysing the uptake of tracer by activated inflammatory cells, PET can provide a quantitative assessment of lung infection and assess the response to therapy. The pulmonary transcapillary escape rate has proved to be significantly higher in areas of radiographic infiltrates in patients with pneumonia compared to normal subjects [123].

Cystic fibrosis patients are characterised by persistent lung inflammation with high levels of neutrophil activation, translating clinically into frequent episodes of lung infections. In patients with cystic fibrosis, PET showed a higher uptake of 18FDG compared to healthy subjects, and this feature positively correlated with the number of neutrophils in the bronchoalveolar lavage fluid [132].

PET has also been proposed in the diagnosis of interstitial lung diseases. In a small group of patients with diffuse interstitial lung disease, the tracer uptake was not different in patients with and without idiopathic pulmonary fibrosis (IPF) [133]. By contrast, in cryptogenic organising pneumonia the tracer uptake was significantly higher compared to IPF and nonspecific interstitial pneumonia (NSIP), while similar levels were detected between IPF and NSIP [134].

\section{COPD}

COPD patients are characterised by significant alterations in the distribution of ventilation and perfusion. By applying an innovative PET analysis, VIDAL et al. [135] analysed ventilation and perfusion within the lung imaging resolution unit (voxel). There was greater perfusion heterogeneity in COPD, compared to in healthy subjects, with no dorsoventral ventilation gradient.

\section{Pleural effusion}

Owing to the intrinsic differences in glucose metabolism between normal and tumour cells, PET can distinguish benign from malignant pleural effusions. Malignant pleural effusions have shown a significantly higher glucose uptake compared to benign effusions, with the technique having good sensitivity and a relatively low specificity in detecting malignant pleural effusions (93\% and $68 \%$, respectively) [136, 137].

\section{EIT}

EIT uses multiple electrodes applied to the external chest surface and the application of a low voltage current to measure both absolute and relative variations of body impedance. A two-dimensional image, of approximately $10 \mathrm{~cm}$, is created with good correlation to intrapulmonary lung gas volume and intrathoracic blood volume. EIT applications range from monitoring mechanical ventilation (PEEP selection, lung recruitability, distribution of ventilation) to estimating lung perfusion and pulmonary function [138-140]. 
Based on our criteria selection, no articles were found on this topic.

\section{Conclusions and need for future research}

Patients with acute respiratory failure due to different lung causes and high mortality risk require numerous lung studies. As a first level examination, CXR, despite its intrinsic limitations and low accuracy, may still play a relevant role. CT remains the gold standard, but it requires patient transportation and use of radiation, which preclude extensive use especially within the same patient. LU, after proper physician training, is able to provide greater accuracy than CXR, similar to that of CT. EIT is gaining a more clinical role after many years as a research tool, while PET has a minimal role in the acute phase of respiratory failure.

As bedside lung imaging techniques, LU and EIT will become more frequently used in patients with acute respiratory failure. Future studies will assess if the information provided will improve clinical management and outcome. Regarding CT, the possibility of dose reduction protocols and safer patient transport to the radiology department will extend its application. There is a clinical need for studies combining different methods for diagnosis and patient monitoring.

Conflict of interest: D. Chiumello has nothing to disclose. G.F. Sferrazza Papa has nothing to disclose. A. Artigas reports grants from Grifols, Fisher \& Paykel, Fundacion Areces and Instituto Carlos III, outside the submitted work. B. Bouhemad has nothing to disclose. A. Grgic reports personal fees from MSD, Boehringer Ingelheim, Roche and Bayer Vital, outside the submitted work. L. Heunks reports personal fees for travel and lecturing from Maquet critical care, and grants from Ventfree and Orionpharma, outside the submitted work. K. Markstaller has nothing to disclose. G.M. Pellegrino has nothing to disclose. L. Pisani has nothing to disclose. D. Rigau works as a methodologist for the ERS. M.J. Schultz has nothing to disclose. G. Sotgiu has nothing to disclose. P. Spieth has nothing to disclose. M. Zompatori has nothing to disclose. P. Navalesi has nothing to disclose.

\section{References}

1 Ranieri VM, Rubenfeld GD, Thompson BT, et al. Acute respiratory distress syndrome: the Berlin Definition. JAMA 2012; 307: 2526-2533.

2 Rubenfeld GD, Caldwell E, Granton J, et al. Interobserver variability in applying a radiographic definition for ARDS. Chest 1999; 116: 1347-1353.

3 Figueroa-Casas JB, Brunner N, Dwivedi AK, et al. Accuracy of the chest radiograph to identify bilateral pulmonary infiltrates consistent with the diagnosis of acute respiratory distress syndrome using computed tomography as reference standard. J Crit Care 2013; 28: 352-357.

4 Fröhlich S, Murphy N, Doolan A, et al. Acute respiratory distress syndrome: underrecognition by clinicians. J Crit Care 2013; 28: 663-668.

5 Peng J-M, Qian C-Y, Yu X-Y, et al. Does training improve diagnostic accuracy and inter-rater agreement in applying the Berlin radiographic definition of acute respiratory distress syndrome? A multicenter prospective study. Crit Care 2017; 21: 12.

6 Goddard SL, Rubenfeld GD, Manoharan V, et al. The Randomized Educational Acute Respiratory Distress Syndrome Diagnosis study: a trial to improve the radiographic diagnosis of acute respiratory distress syndrome. Crit Care Med 2018; 46: 743-748.

7 Halperin BD, Feeley TW, Mihm FG, et al. Evaluation of the portable chest roentgenogram for quantitating extravascular lung water in critically ill adults. Chest 1985; 88: 649-652.

8 Martin GS, Ely EW, Carroll FE, et al. Findings on the portable chest radiograph correlate with fluid balance in critically ill patients. Chest 2002; 122: 2087-2095.

9 Thomason JW, Ely EW, Chiles C, et al. Appraising pulmonary edema using supine chest roentgenograms in ventilated patients. Am J Respir Crit Care Med 1998; 157: 1600-1608.

10 Farshidpanah S, Klein W, Matus M, et al. Validation of the vascular pedicle width as a diagnostic aid in critically ill patients with pulmonary oedema by novice non-radiology physicians-in-training. Anaesth Intensive Care 2014; 42: 321-329.

11 Lefcoe MS, Fox GA, Leasa DJ, et al. Accuracy of portable chest radiography in the critical care setting. Diagnosis of pneumonia based on quantitative cultures obtained from protected brush catheter. Chest 1994; 105: 885-887.

12 Butler KL, Sinclair KE, Henderson VJ, et al. The chest radiograph in critically ill surgical patients is inaccurate in predicting ventilator-associated pneumonia. Am Surg 1999; 65: 805-810.

13 Moine P, Vercken JB, Chevret S, et al. Severe community-acquired pneumococcal pneumonia. The French Study Group of Community-Acquired Pneumonia in ICU. Scand J Infect Dis 1995; 27: 201-206.

14 Schulman CI, Cohn SM, Blackbourne L, et al. How long should you wait for a chest radiograph after placing a chest tube on water seal? A prospective study. J Trauma 2005; 59: 92-95.

15 Pizano LR, Houghton DE, Cohn SM, et al. When should a chest radiograph be obtained after chest tube removal in mechanically ventilated patients? A prospective study. J Trauma 2002; 53: 1073-1077.

16 Emamian SA, Kaasbol MA, Olsen JF, et al. Accuracy of the diagnosis of pleural effusion on supine chest X-ray. Eur Radiol 1997; 7: 57-60.

17 Brixey AG, Luo Y, Skouras V, et al. The efficacy of chest radiographs in detecting parapneumonic effusions. Respirology 2011; 16: 1000-1004.

18 Volpicelli G, Elbarbary M, Blaivas M, et al. International evidence-based recommendations for point-of-care lung ultrasound. Intensive Care Med 2012; 38: 577-591.

19 Copetti R, Soldati G, Copetti P. Chest sonography: a useful tool to differentiate acute cardiogenic pulmonary edema from acute respiratory distress syndrome. Cardiovasc Ultrasound 2008; 6: 16. 

and other causes in the early course of acute hypoxemic respiratory failure. Chest 2015; 148: 912-918. arterial blood gas analysis for the diagnosis of acute respiratory distress syndrome: a pilot study. Crit Care 2015; 19: 282.

22 Huang D, Ma H, Xiao Z, et al. Diagnostic value of cardiopulmonary ultrasound in elderly patients with acute respiratory distress syndrome. BMC Pulm Med 2018; 18: 136.

23 Riviello ED, Kiviri W, Twagirumugabe T, et al. Hospital incidence and outcomes of the acute respiratory distress syndrome using the Kigali modification of the Berlin definition. Am J Respir Crit Care Med 2016; 193: 52-59.

24 Zhao Z, Jiang L, Xi X, et al. Prognostic value of extravascular lung water assessed with lung ultrasound score by chest sonography in patients with acute respiratory distress syndrome. BMC Pulm Med 2015; $15: 98$.

25 Tsubo T, Yatsu Y, Suzuki A, et al. Daily changes of the area of density in the dependent lung region - evaluation using transesophageal echocardiography. Intensive Care Med 2001; 27: 1881-1886.

26 Tsubo T, Sakai I, Suzuki A, et al. Density detection in dependent left lung region using transesophageal echocardiography. Anesthesiology 2001; 94: 793-798.

27 Tsubo T, Yatsu Y, Tanabe T, et al. Evaluation of density area in dorsal lung region during prone position using transesophageal echocardiography. Crit Care Med 2004; 32: 83-87.

28 Stefanidis K, Dimopoulos S, Tripodaki E-S, et al. Lung sonography and recruitment in patients with early acute respiratory distress syndrome: a pilot study. Crit Care 2011; 15: R185.

29 Bouhemad B, Brisson H, Le-Guen M, et al. Bedside ultrasound assessment of positive end-expiratory pressure-induced lung recruitment. Am J Respir Crit Care Med 2011; 183: 341-347.

30 Chiumello D, Mongodi S, Algieri I, et al. Assessment of lung aeration and recruitment by CT scan and ultrasound in acute respiratory distress syndrome patients. Crit Care Med 2018; 46: 1761-1768.

31 Enghard P, Rademacher S, Nee J, et al. Simplified lung ultrasound protocol shows excellent prediction of extravascular lung water in ventilated intensive care patients. Crit Care 2015; 19: 36.

32 Jambrik Z, Monti S, Coppola V, et al. Usefulness of ultrasound lung comets as a nonradiologic sign of extravascular lung water. Am J Cardiol 2004; 93: 1265-1270.

33 Volpicelli G, Skurzak S, Boero E, et al. Lung ultrasound predicts well extravascular lung water but is of limited usefulness in the prediction of wedge pressure. Anesthesiology 2014; 121: 320-327.

34 Mallamaci F, Benedetto FA, Tripepi R, et al. Detection of pulmonary congestion by chest ultrasound in dialysis patients. JACC Cardiovasc Imaging 2010; 3: 586-594.

35 Noble VE, Murray AF, Capp R, et al. Ultrasound assessment for extravascular lung water in patients undergoing hemodialysis. Time course for resolution. Chest 2009; 135: 1433-1439.

36 Lichtenstein DA, Mezière GA, Lagoueyte J-F, et al. A-lines and B-lines: lung ultrasound as a bedside tool for predicting pulmonary artery occlusion pressure in the critically ill. Chest 2009; 136: 1014-1020.

37 Laursen CB, Hänselmann A, Posth S, et al. Prehospital lung ultrasound for the diagnosis of cardiogenic pulmonary oedema: a pilot study. Scand J Trauma Resusc Emerg Med 2016; 24: 96.

38 Cortellaro F, Ceriani E, Spinelli M, et al. Lung ultrasound for monitoring cardiogenic pulmonary edema. Intern Emerg Med 2017; 12: 1011-1017.

39 Martindale JL, Secko M, Kilpatrick JF, et al. Serial sonographic assessment of pulmonary edema in patients with hypertensive acute heart failure. J Ultrasound Med 2018; 37: 337-345.

40 Lichtenstein D, Mézière G, Biderman P, et al. The comet-tail artifact. An ultrasound sign of alveolar-interstitial syndrome. Am J Respir Crit Care Med 1997; 156: 1640-1646.

41 Silva S, Biendel C, Ruiz J, et al. Usefulness of cardiothoracic chest ultrasound in the management of acute respiratory failure in critical care practice. Chest 2013; 144: 859-865.

42 Yang PC, Luh KT, Chang DB, et al. Ultrasonographic evaluation of pulmonary consolidation. Am Rev Respir Dis 1992; 146: 757-762.

43 Testa A, Soldati G, Copetti R, et al. Early recognition of the 2009 pandemic influenza A (H1N1) pneumonia by chest ultrasound. Crit Care 2012; 16: R30.

44 Reissig A, Kroegel C. Sonographic diagnosis and follow-up of pneumonia: a prospective study. Respir Int Rev Thorac Dis 2007; 74: 537-547.

45 Parlamento S, Copetti R, Di Bartolomeo S. Evaluation of lung ultrasound for the diagnosis of pneumonia in the ED. Am J Emerg Med 2009; 27: 379-384.

46 Sperandeo M, Carnevale V, Muscarella S, et al. Clinical application of transthoracic ultrasonography in inpatients with pneumonia. Eur J Clin Invest 2011; 41: 1-7.

47 Cortellaro F, Colombo S, Coen D, et al. Lung ultrasound is an accurate diagnostic tool for the diagnosis of pneumonia in the emergency department. Emerg Med J 2012; 29: 19-23.

48 Reissig A, Copetti R, Mathis G, et al. Lung ultrasound in the diagnosis and follow-up of community-acquired pneumonia: a prospective, multicenter, diagnostic accuracy study. Chest 2012; 142: 965-972.

49 Bourcier J-E, Paquet J, Seinger M, et al. Performance comparison of lung ultrasound and chest X-ray for the diagnosis of pneumonia in the ED. Am J Emerg Med 2014; 32: 115-118.

50 Corradi F, Brusasco C, Garlaschi A, et al. Quantitative analysis of lung ultrasonography for the detection of community-acquired pneumonia: a pilot study. Biomed Res Int 2015; 2015: 868707.

51 Liu X, Lian R, Tao Y, et al. Lung ultrasonography: an effective way to diagnose community-acquired pneumonia. Emerg Med J 2015; 32: 433-438.

52 Pagano A, Numis FG, Visone G, et al. Lung ultrasound for diagnosis of pneumonia in emergency department. Intern Emerg Med 2015; 10: 851-854.

53 Lichtenstein D, Mezière G, Seitz J. The dynamic air bronchogram. A lung ultrasound sign of alveolar consolidation ruling out atelectasis. Chest 2009; 135: 1421-1425.

54 Bouhemad B, Liu Z-H, Arbelot C, et al. Ultrasound assessment of antibiotic-induced pulmonary reaeration in ventilator-associated pneumonia. Crit Care Med 2010; 38: 84-92.

55 Mongodi S, Via G, Girard M, et al. Lung ultrasound for early diagnosis of ventilator-associated pneumonia. Chest 2016; 149: 969-980. 
Lichtenstein D, Mezière G, Biderman $\mathrm{P}$, et al. The lung point: an ultrasound sign specific to pneumothorax. Intensive Care Med 2000; 26: 1434-1440.

Volpicelli G, Boero E, Sverzellati N, et al. Semi-quantification of pneumothorax volume by lung ultrasound. Intensive Care Med 2014; 40: 1460-1467.

Dulchavsky SA, Schwarz KL, Kirkpatrick AW, et al. Prospective evaluation of thoracic ultrasound in the detection of pneumothorax. J Trauma 2001; 50: 201-205.

Kirkpatrick AW, Sirois M, Laupland KB, et al. Hand-held thoracic sonography for detecting post-traumatic pneumothoraces: the Extended Focused Assessment with Sonography for Trauma (EFAST). J Trauma 2004; 57: 288-295.

Weekes AJ, Keller SM, Efune B, et al. Prospective comparison of ultrasound and CXR for confirmation of central vascular catheter placement. Emerg Med J 2016; 33: 176-180.

Vezzani A, Brusasco C, Palermo S, et al. Ultrasound localization of central vein catheter and detection of postprocedural pneumothorax: an alternative to chest radiography. Crit Care Med 2010; 38: 533-538.

Maury E, Guglielminotti J, Alzieu M, et al. Ultrasonic examination: an alternative to chest radiography after central venous catheter insertion? Am J Respir Crit Care Med 2001; 164: 403-405.

Saucier S, Motyka C, Killu K. Ultrasonography versus chest radiography after chest tube removal for the detection of pneumothorax. AACN Adv Crit Care 2010; 21: 34-38.

Lichtenstein D, Hulot JS, Rabiller A, et al. Feasibility and safety of ultrasound-aided thoracentesis in mechanically ventilated patients. Intensive Care Med 1999; 25: 955-958.

Vignon P, Chastagner C, Berkane V, et al. Quantitative assessment of pleural effusion in critically ill patients by means of ultrasonography. Crit Care Med 2005; 33: 1757-1763.

Rozycki GS, Pennington SD, Feliciano DV. Surgeon-performed ultrasound in the critical care setting: its use as an extension of the physical examination to detect pleural effusion. J Trauma 2001; 50: 636-642.

Rocco M, Carbone I, Morelli A, et al. Diagnostic accuracy of bedside ultrasonography in the ICU: feasibility of detecting pulmonary effusion and lung contusion in patients on respiratory support after severe blunt thoracic trauma. Acta Anaesthesiol Scand 2008; 52: 776-784.

Gallard E, Redonnet J-P, Bourcier J-E, et al. Diagnostic performance of cardiopulmonary ultrasound performed by the emergency physician in the management of acute dyspnea. Am J Emerg Med 2015; 33: 352-358.

Yu CJ, Yang PC, Chang DB, et al. Diagnostic and therapeutic use of chest sonography: value in critically ill patients. AJR Am J Roentgenol 1992; 159: 695-701.

Mayo PH, Goltz HR, Tafreshi M, et al. Safety of ultrasound-guided thoracentesis in patients receiving mechanical ventilation. Chest 2004; 125: 1059-1062.

Schleder S, Dornia C, Poschenrieder F, et al. Bedside diagnosis of pleural effusion with a latest generation hand-carried ultrasound device in intensive care patients. Acta Radiol 2012; 53: 556-560.

Awerbuch E, Benavides M, Gershengorn HB. The impact of computed tomography of the chest on the management of patients in a medical intensive care unit. J Intensive Care Med 2015; 30: 505-511.

Owens CM, Evans TW, Keogh BF, et al. Computed tomography in established adult respiratory distress syndrome. Correlation with lung injury score. Chest 1994; 106: 1815-1821. distress syndrome. Comparison with computed tomography. Chest 1991; 100: 762-769.

Puybasset L, Gusman P, Muller JC, et al. Regional distribution of gas and tissue in acute respiratory distress syndrome. III. Consequences for the effects of positive end-expiratory pressure. Intensive Care Med 2000; 26: 1215-1227.

Patroniti N, Bellani G, Maggioni E, et al. Measurement of pulmonary edema in patients with acute respiratory distress syndrome. Crit Care Med 2005; 33: 2547-2554.

Patroniti N, Bellani G, Manfio A, et al. Lung volume in mechanically ventilated patients: measurement by simplified helium dilution compared to quantitative CT scan. Intensive Care Med 2004; 30: 282-289.

$\mathrm{Lu}$ Q, Malbouisson LM, Mourgeon E, et al. Assessment of PEEP-induced reopening of collapsed lung regions in acute lung injury: are one or three CT sections representative of the entire lung? Intensive Care Med 2001; 27: 1504-1510.

Vieira SRR, Nieszkowska A, Lu Q, et al. Low spatial resolution computed tomography underestimates lung overinflation resulting from positive pressure ventilation. Crit Care Med 2005; 33: 741-749.

Reske AW, Costa ELV, Reske AP, et al. Bedside estimation of nonaerated lung tissue using blood gas analysis. Crit Care Med 2013; 41: 732-743.

Caironi $\mathrm{P}$, Carlesso E, Cressoni M, et al. Lung recruitability is better estimated according to the Berlin definition of acute respiratory distress syndrome at standard $5 \mathrm{~cm} \mathrm{H}_{2} \mathrm{O}$ rather than higher positive end-expiratory pressure: a retrospective cohort study. Crit Care Med 2015; 43: 781-790.

Rouby JJ, Puybasset L, Cluzel P, et al. Regional distribution of gas and tissue in acute respiratory distress syndrome. II. Physiological correlations and definition of an ARDS severity score. Intensive Care Med 2000; 26: 1046-1056.

Stelter L, Steffen I, Pinkernelle JG, et al. Computed tomography findings in septic patients with acute respiratory distress syndrome: correlation with survival and pulmonary versus extrapulmonary septic focus. J Comput Assist Tomogr 2013; 37: 602-609.

Lazoura O, Parthipun AA, Roberton BJ, et al. Acute respiratory distress syndrome related to influenza A H1N1 infection: correlation of pulmonary computed tomography findings to extracorporeal membrane oxygenation treatment and clinical outcome. J Crit Care 2012; 27: 602-608.

Simon M, Braune S, Laqmani A, et al. Value of computed tomography of the chest in subjects with ARDS: a retrospective observational study. Respir Care 2016; 61: 316-323.

Chiumello D, Langer $\mathrm{T}$, Vecchi $\mathrm{V}$, et al. Low-dose chest computed tomography for quantitative and visual anatomical analysis in patients with acute respiratory distress syndrome. Intensive Care Med 2014; 40: 691-699.

Klapsing P, Herrmann P, Quintel M, et al. Automatic quantitative computed tomography segmentation and analysis of aerated lung volumes in acute respiratory distress syndrome-A comparative diagnostic study. J Crit Care 2017; 42: 184-191. 
Miller PR, Croce MA, Bee TK, et al. ARDS after pulmonary contusion: accurate measurement of contusion volume identifies high-risk patients. J Trauma 2001; 51: 223-230.

Reske AW, Reske AP, Heine T, et al. Computed tomographic assessment of lung weights in trauma patients with early posttraumatic lung dysfunction. Crit Care 2011; 15: R71.

Chiumello D, Marino A, Cressoni M, et al. Pleural effusion in patients with acute lung injury: a CT scan study. Crit Care Med 2013; 41: 935-944.

Gattinoni L, Bombino M, Pelosi P, et al. Lung structure and function in different stages of severe adult respiratory distress syndrome. JAMA 1994; 271: 1772-1779.

Treggiari MM, Romand J-A, Martin J-B, et al. Air cysts and bronchiectasis prevail in nondependent areas in severe acute respiratory distress syndrome: a computed tomographic study of ventilator-associated changes. Crit Care Med 2002; 30: 1747-1752.

Burnham EL, Hyzy RC, Paine R, et al. Chest CT features are associated with poorer quality of life in acute lung injury survivors. Crit Care Med 2013; 41: 445-456.

Nöbauer-Huhmann IM, Eibenberger K, Schaefer-Prokop C, et al. Changes in lung parenchyma after acute respiratory distress syndrome (ARDS): assessment with high-resolution computed tomography. Eur Radiol 2001; 11: 2436-2443.

Masclans JR, Roca O, Muñoz X, et al. Quality of life, pulmonary function, and tomographic scan abnormalities after ARDS. Chest 2011; 139: 1340-1346.

Kim SJ, Oh BJ, Lee JS, et al. Recovery from lung injury in survivors of acute respiratory distress syndrome: difference between pulmonary and extrapulmonary subtypes. Intensive Care Med 2004; 30: 1960-1963.

Cressoni M, Chiumello D, Carlesso E, et al. Compressive forces and computed tomography-derived positive end-expiratory pressure in acute respiratory distress syndrome. Anesthesiology 2014; 121: 572-581.

Puybasset L, Cluzel P, Gusman P, et al. Regional distribution of gas and tissue in acute respiratory distress syndrome. I. Consequences for lung morphology. Intensive Care Med 2000; 26: 857-869.

Constantin J-M, Grasso S, Chanques G, et al. Lung morphology predicts response to recruitment maneuver in patients with acute respiratory distress syndrome. Crit Care Med 2010; 38: 1108-1117.

Chiumello D, Colombo A, Algieri I, et al. Effect of body mass index in acute respiratory distress syndrome. $\mathrm{Br} J$ Anaesth 2016; 116: 113-121.

Cressoni M, Chiumello D, Algieri I, et al. Opening pressures and atelectrauma in acute respiratory distress syndrome. Intensive Care Med 2017; 43: 603-611.

Cressoni M, Cadringher P, Chiurazzi C, et al. Lung inhomogeneity in patients with acute respiratory distress syndrome. Am J Respir Crit Care Med 2014; 189: 149-158.

Chiumello D, Cressoni M, Carlesso E, et al. Bedside selection of positive end-expiratory pressure in mild, moderate, and severe acute respiratory distress syndrome. Crit Care Med 2014; 42: 252-264.

Constantin J-M, Jaber S, Futier E, et al. Respirato
respiratory distress syndrome. Crit Care 2008; 12: R50.

Galiatsou E, Kostanti E, Svarna E, et al. Prone position augments recruitment and prevents alveolar overinflation in acute lung injury. Am J Respir Crit Care Med 2006; 174: 187-197.

Lu Q, Zhang M, Girardi C, et al. Computed tomography assessment of exogenous surfactant-induced lung reaeration in patients with acute lung injury. Crit Care 2010; 14: R135.

Lu Q, Constantin J-M, Nieszkowska A, et al. Measurement of alveolar derecruitment in patients with acute lung injury: computerized tomography versus pressure-volume curve. Crit Care 2006; 10: R95.

Yoshida T, Rinka H, Kaji A, et al. The impact of spontaneous ventilation on distribution of lung aeration in patients with acute respiratory distress syndrome: airway pressure release ventilation versus pressure support ventilation. Anesth Analg 2009; 109: 1892-1900.

Varpula T, Valta P, Markkola A, et al. The effects of ventilatory mode on lung aeration assessed with computer tomography: a randomized controlled study. J Intensive Care Med 2009; 24: 122-130. lung water. A retrospective analysis in critically ill patients. Scand J Trauma Resusc Emerg Med 2011; 19: 31.

Zhang F, Li C, Zhang J, et al. Comparison of quantitative computed tomography analysis and single-indicator thermodilution to measure pulmonary edema in patients with acute respiratory distress syndrome. Biomed Eng Online 2014; 13: 30.

2 Vergani G, Cressoni M, Crimella F, et al. A morphological and quantitative analysis of lung CT scan in patients with acute respiratory distress syndrome and in cardiogenic pulmonary edema. J Intensive Care Med 2017; in press [DOI: 10.1177/0885066617743477].

Syrjälä H, Broas M, Suramo I, et al. High-resolution computed tomography for the diagnosis of community-acquired pneumonia. Clin Infect Dis 1998; 27: 358-363.

4 Gruden JF, Huang L, Turner J, et al. High-resolution CT in the evaluation of clinically suspected Pneumocystis carinii pneumonia in AIDS patients with normal, equivocal, or nonspecific radiographic findings. AJR Am J Roentgenol 1997; 169: 967-975.

Claessens Y-E, Debray M-P, Tubach F, et al. Early chest computed tomography scan to assist diagnosis and guide treatment decision for suspected community-acquired pneumonia. Am J Respir Crit Care Med 2015; 192: 974-982.

Hockstein NG, Thaler ER, Torigian D, et al. Diagnosis of pneumonia with an electronic nose: correlation of vapor signature with chest computed tomography scan findings. Laryngoscope 2004; 114: 1701-1705.

Nieszkowska A, Lu Q, Vieira S, et al. Incidence and regional distribution of lung overinflation during mechanical ventilation with positive end-expiratory pressure. Crit Care Med 2004; 32: 1496-1503.

Bahloul M, Chaari A, Tounsi A, et al. Incidence and impact outcome of pulmonary embolism in critically ill patients with severe exacerbation of chronic obstructive pulmonary diseases. Clin Respir J 2015; 9: 270-277.

Lichtenstein DA, Mezière G, Lascols N, et al. Ultrasound diagnosis of occult pneumothorax. Crit Care Med 2005; 33: 1231-1238.

Soldati G, Testa A, Sher S, et al. Occult traumatic pneumothorax: diagnostic accuracy of lung ultrasonography in the emergency department. Chest 2008; 133: 204-211.

Xirouchaki N, Magkanas E, Vaporidi K, et al. Lung ultrasound in critically ill patients: comparison with bedside chest radiography. Intensive Care Med 2011; 37: 1488-1493. 
Remérand F, Dellamonica J, Mao Z, et al. Multiplane ultrasound approach to quantify pleural effusion at the bedside. Intensive Care Med 2010; 36: 656-664.

123 Kaplan JD, Calandrino FS, Schuster DP. A positron emission tomographic comparison of pulmonary vascular permeability during the adult respiratory distress syndrome and pneumonia. Am Rev Respir Dis 1991; 143: 150-154.

124 Calandrino FS, Anderson DJ, Mintun MA, et al. Pulmonary vascular permeability during the adult respiratory distress syndrome: a positron emission tomographic study. Am Rev Respir Dis 1988; 138: 421-428.

125 Gattinoni L, Caironi P, Pelosi P, et al. What has computed tomography taught us about the acute respiratory distress syndrome? Am J Respir Crit Care Med 2001; 164: 1701-1711.

126 Sandiford P, Province MA, Schuster DP. Distribution of regional density and vascular permeability in the adult respiratory distress syndrome. Am J Respir Crit Care Med 1995; 151: 737-742. Grecchi E, Veronese M, Moresco RM, et al. Quantification of dynamic [18F]FDG PET studies in acute lung injury. Mol Imaging Biol 2016; 18: 143-152.

128 Bellani G, Messa C, Guerra L, et al. Lungs of patients with acute respiratory distress syndrome show diffuse inflammation in normally aerated regions: a [18F]-fluoro-2-deoxy-D-glucose PET/CT study. Crit Care Med 2009; 37: 2216-2222.

129 Bellani G, Guerra L, Musch G, et al. Lung regional metabolic activity and gas volume changes induced by tidal ventilation in patients with acute lung injury. Am J Respir Crit Care Med 2011; 183: 1193-1199.

130 Cressoni M, Chiumello D, Chiurazzi C, et al. Lung inhomogeneities, inflation and [18F]2-fluoro-2-deoxy-Dglucose uptake rate in acute respiratory distress syndrome. Eur Respir J 2016; 47: 233-242.

131 Schuster DP, Anderson C, Kozlowski J, et al. Regional pulmonary perfusion in patients with acute pulmonary edema. J Nucl Med 2002; 43: 863-870.

132 Chen DL, Ferkol TW, Mintun MA, et al. Quantifying pulmonary inflammation in cystic fibrosis with positron emission tomography. Am J Respir Crit Care Med 2006; 173: 1363-1369.

133 Nusair S, Rubinstein R, Freedman NM, et al. Positron emission tomography in interstitial lung disease. Respirology 2007; 12: 843-847.

134 Umeda Y, Demura Y, Ishizaki T, et al. Dual-time-point 18F-FDG PET imaging for diagnosis of disease type and disease activity in patients with idiopathic interstitial pneumonia. Eur J Nucl Med Mol Imaging 2009; 36: 1121-1130.

135 Vidal Melo MF, Winkler T, Harris RS, et al. Spatial heterogeneity of lung perfusion assessed with (13)N PET as a vascular biomarker in chronic obstructive pulmonary disease. J Nucl Med 2010; 51: 57-65.

136 Nakajima R, Abe K, Sakai S. Diagnostic ability of FDG-PET/CT in the detection of malignant pleural effusion. Medicine (Baltimore) 2015; 94: e1010.

137 Duysinx BC, Larock M-P, Nguyen D, et al. 18F-FDG PET imaging in assessing exudative pleural effusions. Nucl Med Comun 2006; 27: 971-976.

138 Frerichs I, Amato MBP, van Kaam AH, et al. Chest electrical impedance tomography examination, data analysis, terminology, clinical use and recommendations: consensus statement of the TRanslational EIT developmeNt stuDy group. Thorax 2017; 72: 83-93.

139 Walsh BK, Smallwood CD. Electrical impedance tomography during mechanical ventilation. Respir Care 2016; 61: 1417-1424.

140 Riera J, Riu PJ, Casan P, et al. Tomografía de impedancia eléctrica en la lesión pulmonar aguda [Electrical impedance tomography in acute lung injury]. Med Intensiva 2011; 35: 509-517. 